\title{
Organic matter composition and paleoclimatic changes in tropical mountain peatlands currently under grasslands and forest clusters
}

\author{
Alexandre Christófaro Silva ${ }^{\mathrm{a}}$, Maurício Soares Barbosa ${ }^{\mathrm{a}}$, Uidemar Morais Barral ${ }^{\mathrm{a}, *}$, \\ Bárbara Pereira Christófaro Silva ${ }^{\mathrm{b}}$, José Sebastião Cunha Fernandes ${ }^{\mathrm{a}}$, Abraão José Silva Viana ${ }^{\mathrm{a}}$, \\ Carlos Victor Mendonça Filho ${ }^{\mathrm{a}}$, Diêgo Faustolo Alves Bispo ${ }^{\mathrm{b}}$, Cristiano Christófaro ${ }^{\mathrm{a}}$, \\ Carla Ragonezi ${ }^{\mathrm{a}}$, Luiz Roberto Guimarães Guilherme ${ }^{\mathrm{b}}$
}

${ }^{a}$ Federal University of the Jequitinhonha and Mucuri Valleys (UFVJM), 39100-000 Diamantina, Minas Gerais, Brazil

${ }^{\mathrm{b}}$ Federal University of Lavras, $\mathrm{POB}$ 3037, 37200-000 Lavras, Minas Gerais, Brazil

A R T I C L E I N F O

\section{Keywords:}

Organosol

Vegetation types

Altitude

$\mathrm{C}$ and $\mathrm{N}$ isotopes

\begin{abstract}
A B S T R A C T
Tropical peatlands are important ecosystems for Planet Earth, as they store large amounts of carbon and water. A better understanding of the impact of vegetation type and altitude in content, composition, and rate of accumulation of organic matter is key for assessing the current role of such environments. This study evaluated fibric and soluble fractions as well as the lignocellulosic and the isotopic compositions of the peat organic matter from four tropical mountain peatlands located at different altitudes of the Serra do Espinhaço Meridional, state of Minas Gerais, Brazil. The peatlands are currently under grasslands and forest clusters. Samples of peat under both vegetation types were collected and analyzed for organic matter fractions, cellulose, and lignin (van Soest method), as well as carbon and nitrogen isotopes. Different depths were chosen for radiocarbon dating of selected samples. The organic matter of peatlands currently under grasslands and forest clusters presented differences in soluble fractions, lignocellulosic composition, and $\delta^{13} \mathrm{C}$ values. Multivariate analyses allowed grouping the peatlands by altitude and vegetation type. The chronological succession of grassland and forest clusters in tropical mountain peatlands was influenced by altitude and was related to paleoclimatic changes.
\end{abstract}

\section{Introduction}

Peatlands are transitional environments between terrestrial and aquatic ecosystems that provide essential functions for hydrology, ecology, and biogeochemistry (Rezanezhad et al., 2016). These ecosystems are formed from plant remains in places saturated with water and subjected to accumulation of organic matter of dead plant material under conditions of low $\mathrm{pH}$ and oxygen scarcity, resulting in slow humification and mineralization (M.L. Silva et al., 2013).

Peatlands play an important role in global water and carbon cycles, storing approximately $10 \%$ of all water and approximately $30 \%$ of the organic carbon found in soils (Rudiyanto et al., 2015; Rezanezhad et al., 2016).

Peat organic matter is derived from plant tissues composed mainly of lignin, cellulose, and hemicellulose, which together may constitute up to $85 \%$ of the dry biomass of tree species (Canellas and Santos, 2005). Lignin represents 14 to $30 \%$ of the dry biomass of herbaceous matter (Moreira et al., 2006) and 16 to $24 \%$ of the dry biomass of tree species (Klock et al., 2005). Lignin is a significant component of peat organic matter due to slow decomposition rates under anoxic conditions (Williams and Yavitt, 2003). The vegetation type is known to influence the content and composition of lignin and polysaccharides of peat (Schellekens et al., 2012, 2015a). Chronological succession of vegetation type in peatlands may leave signs in the chemical composition of peat.

Plants discriminate carbon differently due to their photosynthetic pathways $\left(\mathrm{C}_{3}, \mathrm{C}_{4}\right.$, and $\mathrm{CAM}$ ), with $\mathrm{C}_{3}$ species (trees and shrubs) discriminating more ${ }^{13} \mathrm{C}(\sim-27 \%)$ than $\mathrm{C}_{4}$ species $(\sim-13 \%)$ (Tipple and Pagani, 2007). The $\delta^{13} \mathrm{C}$ values in peat organic matter can thus be used to identify the photosynthetic pathway of the plants that colonized the site. The removal of compounds that have more or less heavy isotopes than the mean value of the plant tissue alters isotopic signatures during decomposition of peat organic matter. Additionally, the admixture of microbial organic matter in peat organic matter, which generally has a higher content of the heavy isotopes, leads to higher $\delta^{13} \mathrm{C}$ contents (Buurman et al., 2004).

\footnotetext{
* Corresponding author.

E-mail address: uidemarmorais@gmail.com (U.M. Barral).
} 


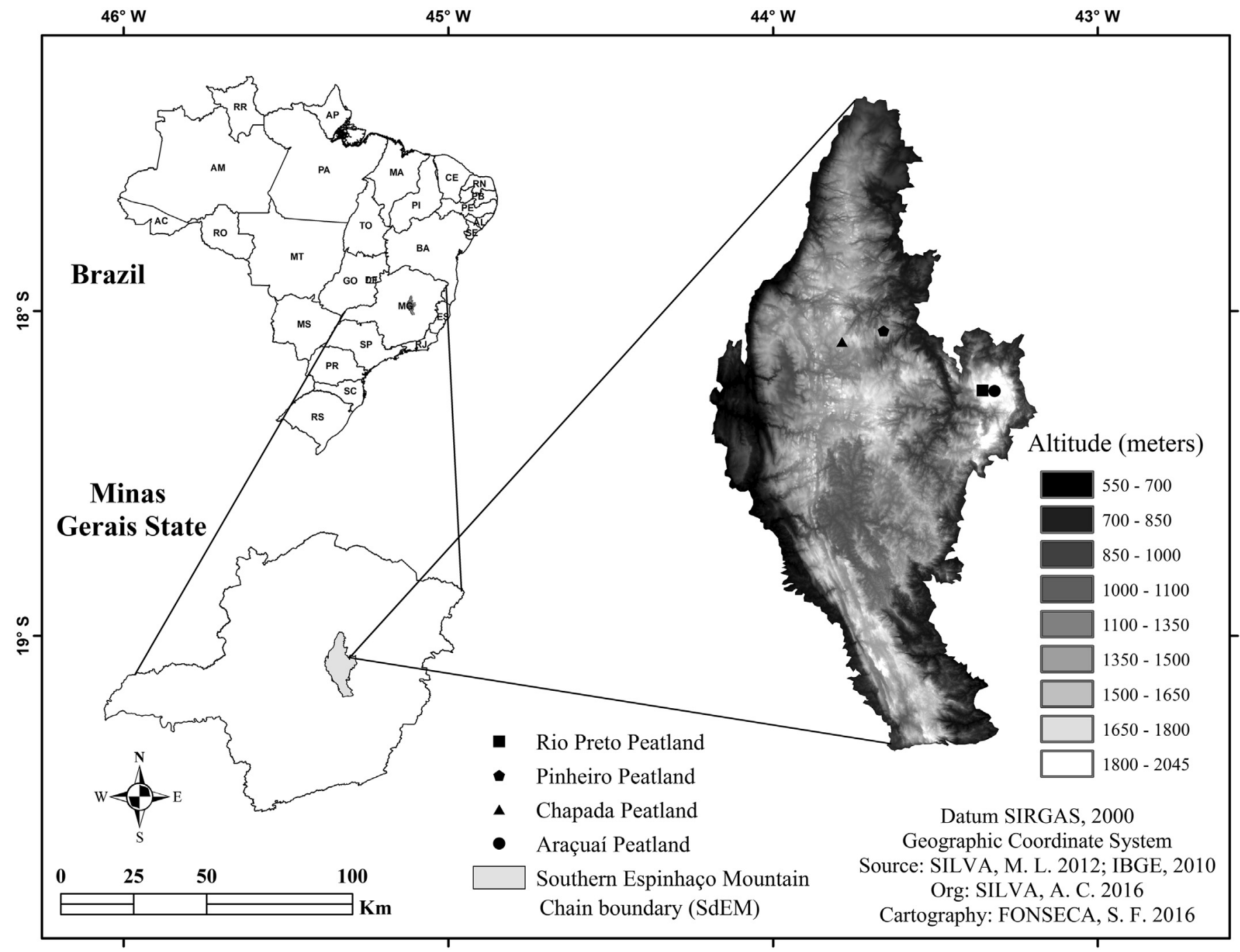

Fig. 1. Geographical location of the four peatlands, situated in the SdEM, state of Minas Gerais, Brazil.

The ${ }^{15} \mathrm{~N}$ content is an indicator of changes in the use of nitrate, denitrification, and $\mathrm{N}_{2}$ fixation, which in turn allows to distinguish the origin of peat organic matter (Lehmann et al., 2002). Atmospheric $\mathrm{N}_{2}$ fixing plants have slightly lower ${ }^{15} \mathrm{~N}$ values than non-fixing plants. Microbial processing of organic matter may lead to selective preservation of ${ }^{15} \mathrm{~N}$ (Evans, 2007). Enriched $\delta^{15} \mathrm{~N}$ values in peat organic matter are indicative of algae $(\sim+6.0 \%)$, whereas depleted values $(\sim$ $+0.5 \%$ ) indicate terrestrial plants (Peterson and Howard, 1987).

In Brazil, peatlands occupy approximately $0.07 \%$ of the territory (Valladares et al., 2008). The Serra do Espinhaço Meridional (SdEM), located in the state of Minas Gerais, Brazil, is one of the few mountainous regions where peatlands have been formed at an altitude between $1200 \mathrm{~m}$ and $2000 \mathrm{~m}$ since the Pleistocene (Horák-Terra et al., 2014). They occupy $>14,000$ ha and hold approximately 142 million $\mathrm{m}^{3}$ of water and approximately 3.6 million tons of carbon (M.L. Silva et al., 2013). These tropical peats are distinguished from northern peatlands by the absence of sphagnum acid (Schellekens et al., 2015b). The SdEM separates the Atlantic Forest biome from the Cerrado biome (Ribeiro et al., 2009; Santos et al., 2011). Little is known about the influence of the Atlantic Forest and Cerrado biomes on peatland vegetation cover. Recent studies have shown that forest clusters in the east and west of the SdEM present a different floristic composition that may be related to altitude, climate, and soil (Santos et al., 2011). The microclimate is directly influenced by altitude, with a decreasing temperature of approximately $1{ }^{\circ} \mathrm{C} / 100 \mathrm{~m}$, caused by a decrease in air density, an increasing cloudiness, and greater wind exposure (Dury, 1972; Ometto, 1981). According to the Nernst equation the increase in temperature favors oxidation and, of course, the decay of the peat organic matter.

The peatlands of SdEM are found at different altitudes colonized by herbaceous, and shrub species (grasslands - C3 and C4 photosynthetic pathways), as well as tree species (forest clusters - C3 photosynthetic pathways) (Campos et al., 2012; Horák et al., 2011). Grassland and forest clusters vary in the species composition, phytomass production, and lignocellulosic composition of the plant material (V.E. Silva et al., 2013). This work aimed at evaluating the chemical and isotopic composition of the peat organic matter of four tropical mountain peatlands of different altitudes, situated in SdEM, currently under grasslands and forest clusters.

Our hypotheses for this study are: a) altitude influences the floristic composition of grassland and forest clusters; b) vegetation type and altitude impact the content and the composition of peat organic matter; c) paleoclimatic changes promoted a chronological succession of grassland and forest clusters in peatlands.

\section{Material and methods}

\subsection{Study area}

The study area is located in the SdEM (state of Minas Gerais, Brazil), 
in which quartzite rocks predominate, with altitudes varying from $1000 \mathrm{~m}$ and $2000 \mathrm{~m}$. The relief is extremely mountainous and steep in the valleys and flat to softly undulating on the flat surfaces. The climate is C'wb (mesothermal), according to the Köppen classification; a rainy season occurs from November to March (monthly average precipitation of $223 \mathrm{~mm}$ ) and a dry season lasts from May to September (monthly average precipitation of $8 \mathrm{~mm}$ ). The seasons are well defined, and the average annual temperature is $18.7^{\circ} \mathrm{C}$ (E.V. Silva et al., 2013). At $1600 \mathrm{~m}$ of altitude, the average annual temperature is $16.2^{\circ} \mathrm{C}$ (Costa, 2018).

The studied peatlands are located in the depressions of plane surfaces and are currently under two vegetation types that are found at altitudes above $1000 \mathrm{~m}$, on the Diamantina Plateau (Mendonça Filho, 2005): grasslands and forest clusters. The grasslands are composed predominantly by herbaceous plants, with species adapted to poor drainage conditions and dominated by families such as Cyperaceae, Eriocaulaceae, Poaceae, and Xyridaceae (Munhoz and Felfili, 2008; Ribeiro et al., 2009). The forest clusters are "islands" of semi-deciduous, high-mountain, seasonal forests (Veloso et al., 1991) surrounded by grasslands and exhibiting different but mainly circular shapes (Meguro et al., 1996a; Horák et al., 2011; Santos et al., 2011), whose local name is Capões.

The four peatlands studied are located in: A) Chapada $(L C H)$ : $18^{\circ} 3^{\prime} 46.4^{\prime \prime}$ and $18^{\circ} 3^{\prime} 37.3^{\prime \prime} \mathrm{S}$ and $43^{\circ} 39^{\prime} 41.4^{\prime \prime}$ and $43^{\circ} 39^{\prime} 29.8^{\prime \prime}$ WGR; B) Pinheiro (LPN): $18^{\circ} 16^{\prime} 22^{\prime \prime}$ and $18^{\circ} 15^{\prime} 17^{\prime \prime} S$ and $43^{\circ} 41^{\prime} 10^{\prime \prime}$ and $43^{\circ} 39^{\prime} 15^{\prime \prime}$ WGR; C) Rio Preto (HRP): $18^{\circ} 14^{\prime \prime} 7.02^{\prime \prime}$ and $18^{\circ} 14^{\prime} 3.63^{\prime \prime} \mathrm{S}$ and $43^{\circ} 19^{\prime} 10.86^{\prime \prime}$ and $43^{\circ} 19^{\prime \prime} 7.66^{\prime \prime}$ WGR; D) Araçuaí (HAR):18 $14^{\prime} 30.18^{\prime \prime}$ and $18^{\circ} 14^{\prime} 26.4^{\prime \prime} \mathrm{S}$ and $43^{\circ} 18^{\prime} 37.58^{\prime \prime}$ and $43^{\circ} 18^{\prime} 33.94^{\prime \prime}$ WGR. The peatlands $L C H$ and $L P N$ are located, respectively, at 1320 and $1240 \mathrm{~m}$ of altitude (lower altitudes). The peatlands HRP and HAR are located, respectively, at 1598 and $1593 \mathrm{~m}$ of altitude (higher altitudes) (Fig. 1).

\subsection{Collection of the botanical material}

An inventory of plant species was performed in all four SdEM peatlands investigated. The collections were made in March 2012 ( $L C H$ and $L P N$ ) and July 2012 ( $L R P$ and $L A R$ ), periods with higher number of species with flower buds at each altitude. The collected material was georeferenced and the samples received the traditional treatment used in floristic surveys: pressing, drying in an electric dryer, and storage as exsiccate. The collected specimens were deposited in the Herbarium of Universidade Federal dos Vales do Jequitinhonha e Mucuri (Herbário DIAM), Diamantina, Minas Gerais, Brazil.

\subsection{Peat sampling}

A vibracore was used to collect two cores in each peatland (under grasslands and forest clusters). The cores were opened in the laboratory and samples were taken every $15 \mathrm{~cm}$ down to the depths of: $200 \mathrm{~cm}$ (grasslands) or $215 \mathrm{~cm}$ (forest clusters), for peatland $H R P ; 150 \mathrm{~cm}$ (grasslands) or $225 \mathrm{~cm}$ (forest clusters), for HAR; $105 \mathrm{~cm}$ (grasslands) or $135 \mathrm{~cm}$ (forest clusters) for $L C H ; 150 \mathrm{~cm}$ (grasslands) or $90 \mathrm{~cm}$ (forest clusters) for $L P N$. The collection, sampling and transport of the material followed the methodology described by Horák et al. (2011). Data from samples collected down to $90 \mathrm{~cm}$, which corresponds to the depth of the shallowest peat, were used for the analysis of variance.

\subsection{Determination of fibric and soluble fractions and lignocellulosic composition}

The samples were first air-dried and passed through 2-mm sieves, and then placed in an oven with air circulating at a temperature of $50{ }^{\circ} \mathrm{C}$, for $12 \mathrm{~h}$. Fractionation of soil organic matter followed the procedure described by Canellas and Santos (2005), with fractions being classified as soluble (i.e., fulvic acids - $F A$, first extracted with base and then with acid; and, humic acids - $H A$, dissolved in base and then precipitated with acid), and insoluble (fibric fraction - FF).

To isolate lignin and cellulose from the samples, a solution of acid detergent (van Soest, 1994) was first used to obtain cellulose, lignin, and insoluble ash residue (acid detergent fibre - $A D F$ ). To determine the contents of lignin and cellulose, two sub-samples of $A D F$ were next separated; in the first one, lignin was oxidized with a solution of acetic acid and potassium permanganate, leaving cellulose and insoluble ash as a residue, while in the second sample, cellulose was oxidized by sulfuric acid to leave lignin and other non-oxidized materials and insoluble ash as a residue. The cellulose and lignin (cellulose and lignin van Soest method) contents were determined after heating the $A D F$ subsamples in a muffle furnace at $500^{\circ} \mathrm{C}$ for $3 \mathrm{~h}$.

\subsection{Determination of $C$ and $N$ isotopes}

For determination of isotopic compositions, the samples were ovendried at $40^{\circ} \mathrm{C}$, homogenized in an agate mortar, and weighed in tin capsules. Approximately $3.5 \mathrm{mg}$ of each sample was used to determine the $\delta^{13} \mathrm{C}$ and $\delta^{15} \mathrm{~N}$ values in a mass spectrometer (Groning and Groot, 2004).

For radiocarbon dating, three samples (2-cm layers) were collected at different depths of each peatland, according to the morphological attributes and the organic carbon content of the layer. One additional sample was collected in PN under the forest cluster. After sampling, the decomposed organic matter was removed by dissolution in base and then in acid. Next, the samples were washed with distilled water and the residue $(F F)$ was sent for dating. The radiocarbon ages of the samples were determined in the ${ }^{14} \mathrm{C}$ Laboratory of CENA/USP, São Paulo, Brazil, according to a method proposed by Pessenda et al. (1983) and Stuiver et al. (2017).

\subsection{Statistical analysis}

To test the hypothesis that vegetation type and altitude influences the content and composition of peat organic matter and that paleoclimatic changes promoted a chronological succession of grassland and forest clusters, peatland ( $L R P, L A R, L C H$, and $L P N)$, vegetation type (grasslands and forest clusters), and depth (down to $90 \mathrm{~cm}$, which corresponds to the depth of the shallowest peat) were the factors considered for analyzes. The evaluated variables were the contents of $F A$, $H A, F F$, "van Soest lignin" and "van Soest cellulose", as well as the composition of $\delta^{13} \mathrm{C}$ and $\delta^{15} \mathrm{~N}$ and the $\mathrm{C} / \mathrm{N}$ ratio. The effects of these factors on each of the variables evaluated were tested by the $\mathrm{F}$ test using the following model: $y_{i j k}=m+t_{i}+f_{j}+t_{i j}+p_{k}+e_{i j k}$, where $t_{i}$ refers to the effect of peatland $i$ with four levels; $f_{j}$ refers to the effect of vegetation type $\mathrm{j}$, with two levels; $\mathrm{tf}_{\mathrm{ij}}$ refers to the effect of the interaction between these two factors; $p_{k}$ refers to the effect of depth $k$, with six levels; and $\mathrm{e}_{\mathrm{ijk}}$ refers to the residue, following a cross-classification. The averages of each variable were compared using the Tukey test (p $<0.05)$.

For a better understanding of how peatlands are grouped by vegetation type and altitude, multivariate clustering and stepwise discriminant analysis were performed. Since collinearity may negatively interfere with multivariate analyses (Hair et al., 2009), the redundant variables were eliminated, leaving only one of the highly correlated variables. Therefore, $F F$, "van Soest lignin", "van Soest cellulose", $\delta^{13} \mathrm{C}$, and $\delta^{15} \mathrm{~N}$ were included in multivariate clustering. $F A$ and $H A$ were eliminated, as they were highly correlated with $F F$. The multivariate clustering was used to elaborate a dendrogram based on dissimilarities using mean Euclidean distances and hierarchical grouping generated by the Ward method. The measurement of dissimilarities was made using the variables in their respective units of evaluation, that is, without any type of standardization. The Genes software was used for the analysis (Cruz, 2006).

The stepwise discriminant analysis was performed in all data to determine the most important variables to for differentiating the 
peatlands. Thus, for each peatland, a discriminant function was generated (Johnson and Wichern, 1992):

$f\left(G_{i}\right)=k_{i}+\sum_{j=1}^{n} w_{i j} p_{i j}$

In this formula, $i$ is the number of groups (grasslands), $k_{i}$ is the inherent constant for each group, $\mathrm{n}$ is the number of parameters used to classify a sample into one of the groups, $\mathrm{w}_{\mathrm{j}}$ is the weighted coefficient, defined by the stepwise discriminant analysis for a given parameter $\left(\mathrm{p}_{\mathrm{j}}\right)$. The spatial variation of the parameters analyzed in the peatlands was evaluated using the stepwise discriminant analysis method. Three discriminant functions $(L D)$ were generated among the four peatlands. The functions were considered statistically significant according to the Wilks lambda test.

Peatlands were considered the dependent variables, whereas the parameters measured were the independent variables. The relative contribution of each variable in the separation of groups was also evaluated. The discriminant analysis was performed with the $\mathrm{R}$ software.

\section{Results}

\subsection{Floristic composition of the grasslands and forest clusters}

Forest clusters are sparsely distributed (3-17 in each peatland), with a circular shape 5 to $100 \mathrm{~m}$ in diameter (Fig. 2), occupying between 2.7 and $13.6 \%$ of the peatland (Table 1). M.L. Silva et al. (2013) mapped 19 isolates of forest clusters in 82 ha of peatland of the SdEM, occupying an area of 2.6 ha (3.2\% of the total area). These authors identified four dominant species in forest clusters and 11 dominant species in grasslands. The number of dominant species ranged from 12 to 28 and from 6 to 10 for grasslands and forest clusters, respectively (Table 1), with nine (29\%) from the grasslands and five (50\%) from forest clusters common to all four peatlands.

Twenty-four families, 36 genera and 42 species were identified. Of these families, 15 families were found in grasslands, and five of these were common to all the peatlands: Cyperaceae, Eriocaulaceae, Iridaceae, Poaceae, and Xyridaceae. In forest clusters, 10 families were identified, of which five families and their respective species were common to all the peatlands studied. Nineteen of the 31 species found
Table 1

Number of forest clusters, area and number of dominant species in grassland (G) and forest clusters (F) in four peatlands of the SdEM.

\begin{tabular}{|c|c|c|c|c|c|c|}
\hline \multirow[t]{3}{*}{ Peatland } & \multirow[t]{3}{*}{ No of forest clusters } & \multicolumn{3}{|l|}{ Area } & \multicolumn{2}{|c|}{ Dominant species $^{\mathrm{a}}$} \\
\hline & & \multirow{2}{*}{$\begin{array}{l}\text { Total } \\
\text { ha }\end{array}$} & $\mathrm{F}$ & G & \multirow[t]{2}{*}{$\mathrm{F}$} & \multirow[t]{2}{*}{ G } \\
\hline & & & $\%$ & & & \\
\hline $\mathrm{LCH}$ & 3 & 9.8 & 6.1 & 93.9 & 6 & 12 \\
\hline$L P N$ & 6 & 44.9 & 13.6 & 86.4 & 6 & 12 \\
\hline HAR & 16 & 80.3 & 2.7 & 97.3 & 10 & 28 \\
\hline HRP & 17 & 20.8 & 3.8 & 96.2 & 10 & 28 \\
\hline
\end{tabular}

a Identified in Table 2.

in grasslands and 5 of the 11 species found in forest clusters only occur in peatlands $H A R$ and $H R P$, whereas 3 of the 31 species found in grasslands and 1 of the 11 species found in forest clusters only occur only in peatlands $L C H$ and $L P N$ (Table 2).

\subsection{Vegetation type, altitude, and content and composition of peat organic} matter

\subsubsection{Vegetation type}

The levels of $F A$, "van Soest lignin", "van Soest cellulose", and $\delta^{13} \mathrm{C}$ were higher in forest clusters (ANOVA, $\mathrm{p}=0.046,0.002,0.000$ and 0.000 , respectively), whereas $H A$ contents were higher in grasslands (ANOVA, $\mathrm{p}=0.000$ ) and $F F$ and $\delta^{15} \mathrm{~N}$ contents exhibited no differences among the vegetation types (Table 3 ).

The levels of FF and "van Soest lignin" are higher on the surface in forest clusters and the levels of $H A$ and $\delta^{13} \mathrm{C}$ are higher on the surface in grasslands. In the layer of 45 to $90 \mathrm{~cm}$ of depth, the levels of $F F, F A, H A$, $\delta^{15} \mathrm{~N}, \delta^{13} \mathrm{C}$, and $\mathrm{C} / \mathrm{N}$ ratio of peat under grasslands and forest clusters tend to be similar (Figs. 3, 4, 5 and 6).

The mean, maximal and minimal values of $\delta^{13} \mathrm{C}$ were lower under forest clusters than under grasslands (Table 3 and Fig. 7). However, in the layer of 45 to $90 \mathrm{~cm}$ of depth these levels under grasslands and forest clusters were comparable (Fig. 5).

\subsubsection{Altitude}

The $L P N$ and $L C H$ (lower altitudes, higher temperatures) peatlands

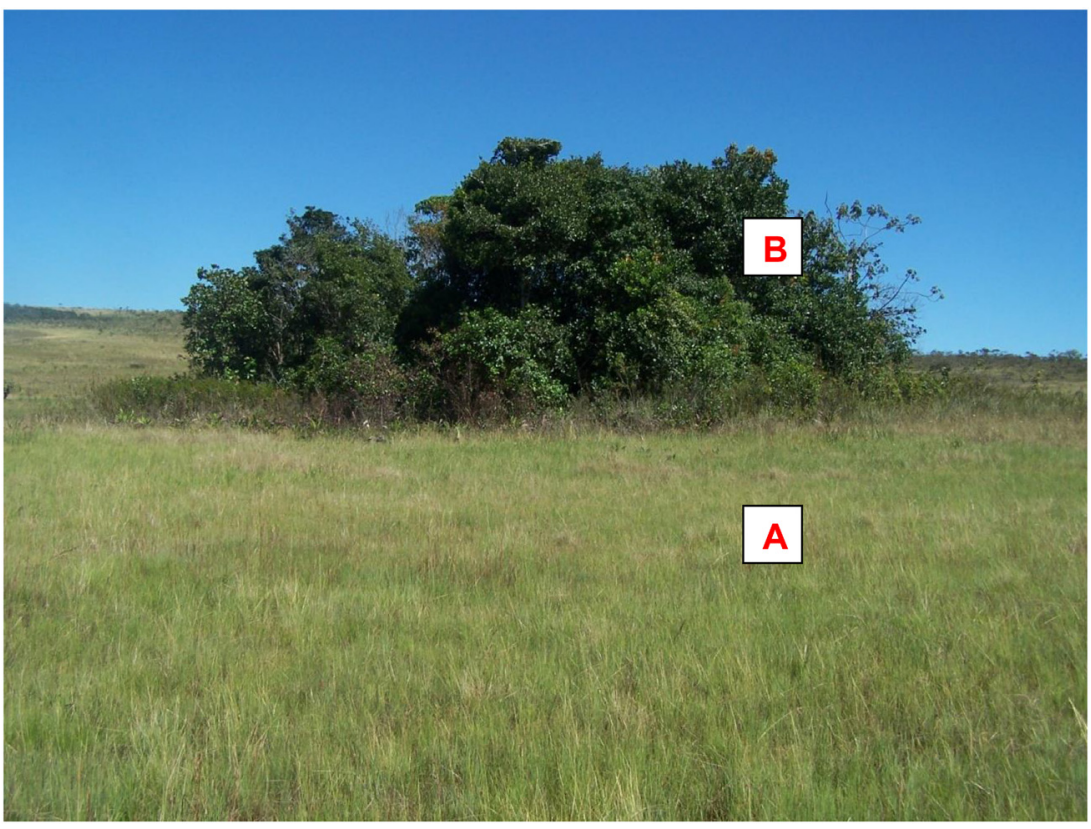

Fig. 2. Peatlands characteristic vegetation: A) grasslands $(G)$ and B) forest clusters $(F)$. 
Table 2

Predominant species in the grasslands $(\mathrm{G})$ and forest clusters $(\mathrm{F})$ that colonize four peatlands and their $\delta^{13} \mathrm{C}$

\begin{tabular}{|c|c|c|c|c|c|c|c|}
\hline \multirow[t]{2}{*}{ Family } & \multirow[t]{2}{*}{ Species } & \multirow[t]{2}{*}{ Vegetation types } & \multicolumn{4}{|c|}{ Peatland } & \multirow{2}{*}{$\begin{array}{l}\delta^{13} C^{*} \\
\% 0\end{array}$} \\
\hline & & & $L C H$ & $L P N$ & HAR & $H R P$ & \\
\hline Cyperaceae & Lagenocarpus rigidus Nees & G & $\mathrm{x}$ & $\mathrm{x}$ & $\mathrm{x}$ & $\mathrm{x}$ & 27.60 \\
\hline Cyperaceae & Lagenocarpus tenuifolius Kuntze & G & $\mathrm{x}$ & $\mathrm{x}$ & $\mathrm{x}$ & $\mathrm{x}$ & 26.85 \\
\hline Cyperaceae & Rhynchospora speciosa (Kunth) Boeckeler & G & $\mathrm{x}$ & $\mathrm{x}$ & $\mathrm{x}$ & $\mathrm{x}$ & 26.01 \\
\hline Eriocaulaceae & Leiothrix flavescens (Bong) Ruhland & G & $\mathrm{x}$ & $\mathrm{x}$ & $\mathrm{x}$ & $\mathrm{x}$ & - \\
\hline Eriocaulaceae & Paepalanthus macrocephalus (Bong) Körn & G & $\mathrm{x}$ & $\mathrm{x}$ & $\mathrm{x}$ & $\mathrm{x}$ & 26.08 \\
\hline Xyridaceae & Xyris sp. 1 & G & $\mathrm{x}$ & $\mathrm{x}$ & $\mathrm{x}$ & $\mathrm{x}$ & 25.60 \\
\hline Iridaceae & Trimezia juncifolia (Klatt) Benth. \& Hook & G & $\mathrm{x}$ & $\mathrm{x}$ & $\mathrm{x}$ & $\mathrm{x}$ & - \\
\hline Poaceae & $N I$ & G & $\mathrm{x}$ & $\mathrm{x}$ & $\mathrm{x}$ & $\mathrm{x}$ & - \\
\hline Poaceae ${ }^{* *}$ & Loudetiopsis chrysothrix (Nees) Conert & G & $\mathrm{x}$ & $\mathrm{x}$ & $\mathrm{x}$ & $\mathrm{x}$ & 13.37 \\
\hline Xyridaceae & Abolboda pulchella Humb. & G & $\mathrm{x}$ & $\mathrm{x}$ & - & - & - \\
\hline Eriocaulaceae & Paepalanthus sp. 2 & G & $\mathrm{x}$ & $\mathrm{x}$ & - & - & 27.66 \\
\hline Xyridaceae & Xyris sp. 2 & G & $\mathrm{x}$ & $\mathrm{x}$ & - & - & 27.88 \\
\hline Araceae & Philodendron uliginosum Mayo & G & - & - & $\mathrm{x}$ & $\mathrm{x}$ & 25.62 \\
\hline Asteraceae & Achyrocline satureioides (Lam.) DC. & G & - & - & $\mathrm{x}$ & $\mathrm{x}$ & - \\
\hline Asteraceae & Baccharis trimera (Less.) DC. & G & - & - & $\mathrm{x}$ & $\mathrm{x}$ & 28.75 \\
\hline Asteraceae & Trixis nobilis (Vell.) Katinas & G & - & - & $\mathrm{x}$ & $\mathrm{x}$ & - \\
\hline Ericaceae & Gaylussacia brasiliensis (Spreng) Mart. & G & - & - & $\mathrm{x}$ & $\mathrm{x}$ & 26.01 \\
\hline Eriocaulaceae & Comanthera xeranthemoides (Bong) L.R.Parra \& Giul. & G & - & - & $\mathrm{x}$ & $\mathrm{x}$ & - \\
\hline Eriocaulaceae & Syngonanthus sp. & G & - & - & $\mathrm{x}$ & $\mathrm{x}$ & - \\
\hline Eriocaulaceae & Syngonanthus elegans (Bong.) Ruhland & G & - & - & $\mathrm{x}$ & $\mathrm{x}$ & - \\
\hline Eriocaulaceae & Syngonanthus nitens Ruhland & G & - & - & $\mathrm{x}$ & $\mathrm{x}$ & - \\
\hline Euphorbiaceae & Croton campestris A.St.-Hil & G & - & - & $\mathrm{x}$ & $\mathrm{x}$ & - \\
\hline Fabaceae & Chamaecrista distichoclada (Benth.) H.S.Irwin \& Barneby & G & - & - & $\mathrm{x}$ & $\mathrm{x}$ & - \\
\hline Fabaceae & Crotalaria flavicoma Benth. & G & - & - & $\mathrm{x}$ & $\mathrm{x}$ & - \\
\hline Lythraceae & Cuphea micrantha Kunth & G & - & - & $\mathrm{x}$ & $\mathrm{x}$ & - \\
\hline Melastomataceae & Microlicia Glandulifera Cogn. & G & - & - & $\mathrm{x}$ & $\mathrm{x}$ & - \\
\hline Melastomataceae & Lavoisiera imbricata (Thunb.) DC. & G & - & - & $\mathrm{x}$ & $\mathrm{x}$ & - \\
\hline Poaceae & Chusquea pinifolia (Nees) Nees & G & - & - & $\mathrm{x}$ & $\mathrm{x}$ & - \\
\hline Polygalaceae & Polygala celosioides Mart. Ex A.W.Benn. & G & - & - & $\mathrm{x}$ & $\mathrm{x}$ & - \\
\hline Rubiaceae & Galianthe sp. & G & - & - & $\mathrm{x}$ & $\mathrm{x}$ & - \\
\hline Verbenaceae & Stachytarpheta reticulata Mart. ex Schauer & G & - & - & $\mathrm{x}$ & $\mathrm{x}$ & - \\
\hline Anacardiaceae & Tapirira guianensis Aubl. & $\mathrm{F}$ & $\mathrm{x}$ & $\mathrm{x}$ & $\mathrm{x}$ & $\mathrm{x}$ & - \\
\hline Araliaceae & Schefflera calva (Cham.) Frodin \& Fiaschi & $\mathrm{F}$ & $\mathrm{x}$ & $\mathrm{x}$ & $\mathrm{x}$ & $\mathrm{x}$ & - \\
\hline Burseraceae & Protium heptaphyllum Marchand & $\mathrm{F}$ & $\mathrm{x}$ & $\mathrm{x}$ & $\mathrm{x}$ & $\mathrm{x}$ & 29.39 \\
\hline Calophyllaceae & Calophyllum brasiliense Cambess & $\mathrm{F}$ & $\mathrm{x}$ & $\mathrm{x}$ & $\mathrm{x}$ & $\mathrm{x}$ & 30.85 \\
\hline Melastomataceae & Tibouchina sp. & $\mathrm{F}$ & $\mathrm{x}$ & $\mathrm{x}$ & $\mathrm{x}$ & $\mathrm{x}$ & 29.30 \\
\hline Chloranthaceae & Hedyosmum brasiliensis Mart. & $\mathrm{F}$ & $\mathrm{x}$ & $\mathrm{x}$ & - & - & - \\
\hline Lauraceae & Nectandra sp. & $\mathrm{F}$ & - & - & $\mathrm{x}$ & $\mathrm{x}$ & - \\
\hline Lauraceae & Ocotea sp. & $\mathrm{F}$ & - & - & $\mathrm{x}$ & $\mathrm{x}$ & - \\
\hline Myrtaceae & Myrcia splendens (Sw.) DC. & $\mathrm{F}$ & - & - & $\mathrm{x}$ & $\mathrm{x}$ & - \\
\hline Rubiaceae & Rudgea sessilis (Vell.) Müll. Arg. & $\mathrm{F}$ & - & - & $\mathrm{x}$ & $\mathrm{x}$ & - \\
\hline Sapindaceae & Matayba sp. & $\mathrm{F}$ & - & - & $\mathrm{x}$ & $\mathrm{x}$ & - \\
\hline
\end{tabular}

Ni: unidentified; *: M.L. Silva et al. (2013); x: present; **: photosynthetic cycle C4.

Table 3

Average values and standard deviation (SD) of $F A, H A, F F$, "van Soest lignin", "van Soest cellulose", $\delta^{13} \mathrm{C}$ and $\delta^{15} \mathrm{~N}$ in four peatlands of the SdEM currently under grasslands (G) and forest clusters (F).

\begin{tabular}{|c|c|c|c|c|c|c|c|}
\hline \multirow{2}{*}{$\begin{array}{l}\text { Vegetation } \\
\text { types }\end{array}$} & $F A$ & $H A$ & $F F$ & Lig & Cel & $\delta^{13} \mathrm{C}$ & $\delta^{15} \mathrm{~N}$ \\
\hline & \multicolumn{5}{|c|}{$\%$ of $\mathrm{POM}$} & \multicolumn{2}{|l|}{$\%$} \\
\hline G & $\begin{array}{l}11.6 \mathrm{~b} \\
(3.1)^{*}\end{array}$ & $\begin{array}{c}14.0 \mathrm{a} \\
(3.1)\end{array}$ & $\begin{array}{c}74.4 \mathrm{a} \\
(5.3)\end{array}$ & $\begin{array}{c}16.2 \mathrm{~b} \\
(5.4)\end{array}$ & $\begin{array}{l}17.4 \mathrm{~b} \\
(5.9)\end{array}$ & $\begin{array}{c}-20.9 \mathrm{~b} \\
(1.4)\end{array}$ & $\begin{array}{l}4.0 \mathrm{a} \\
(1.7)\end{array}$ \\
\hline $\mathrm{F}$ & $\begin{array}{l}13.1 \mathrm{a} \\
(5.9)\end{array}$ & $\begin{array}{c}10.8 \mathrm{~b} \\
(1.9)\end{array}$ & $\begin{array}{c}76.2 \mathrm{a} \\
(6.7)\end{array}$ & $\begin{array}{l}22.2 \mathrm{a} \\
(6.4)\end{array}$ & $\begin{array}{l}22.3 \mathrm{a} \\
(6.1)\end{array}$ & $\begin{array}{c}-23.4 \mathrm{a} \\
(1.8)\end{array}$ & $\begin{array}{l}4.6 \mathrm{a} \\
(1.5)\end{array}$ \\
\hline
\end{tabular}

POM: peat organic matter; *: SD. Means followed by the same letter in the columns did not differ by Tukey's test $(\mathrm{p}<0.05)$. Number of observations (n) $=24$.

had higher mean levels of $F A$ (ANOVA, p $=0.000$ ), lower $F F$ and "van Soest cellulose" (ANOVA, p $=0.000$ and 0.000 , respectively) and higher values of $\delta^{13} \mathrm{C}$ (ANOVA, $\mathrm{p}=0.000$ ). The contents of $H A$ and "van Soest lignin" as well as the $\delta^{15} \mathrm{~N}$ values did not differ among peatlands (Table 4).

In peat under grasslands of higher altitudes, the levels of $F A$ and $H A$ (peatland $L R P$ ), and "van Soest lignin" (peatland $L A R$ ) tend to increase with depth. Opposite trends are found in peat under grasslands of lower altitudes ( $L P N$ and $L C H$ ). In peat under forest clusters of higher altitudes ( $L R P$ and $L A R$ ), the levels of FA and "van Soest cellulose" tend to increase with depth and the levels of "van Soest lignin" tend to decrease with depth. Opposing trends are found in peat under forest clusters of lower altitudes ( $L P N$ and $L C H)$.

The mean levels of FA (soluble) are higher and the mean levels of $F F$ are lower in peats of lower altitudes ( $L P N$ and $L C H$ - older) (Table 4).

The $\mathrm{C} / \mathrm{N}$ ratio increases with depth (ANOVA, $\mathrm{p}=0.000$ ), In the layer of 45 to $90 \mathrm{~cm}$ of depth, the levels of $\delta^{13} \mathrm{C}$ and $\mathrm{C} / \mathrm{N}$ ratio under grasslands and forest clusters in all peatlands tend to be comparable (Figs. 3 and 5).

\subsection{Grouping of peatlands by vegetation type and altitude}

The dendrogram (Fig. 8) illustrates the formation of the two main blocks separating the peatlands $L R P$ and $L A R$ (higher altitudes) and $L P N$ and $L C H$ (lower altitudes). Differences were also observed between the variables in grasslands and forest clusters, but this difference is smaller than that verified between the higher ( $L R P$ and $L A R$ ) and lower peatlands ( $L P N$ and $L C H)$.

The data analysis of the variables at all depths under the two vegetation types, considering the first two discriminant functions (LD1 


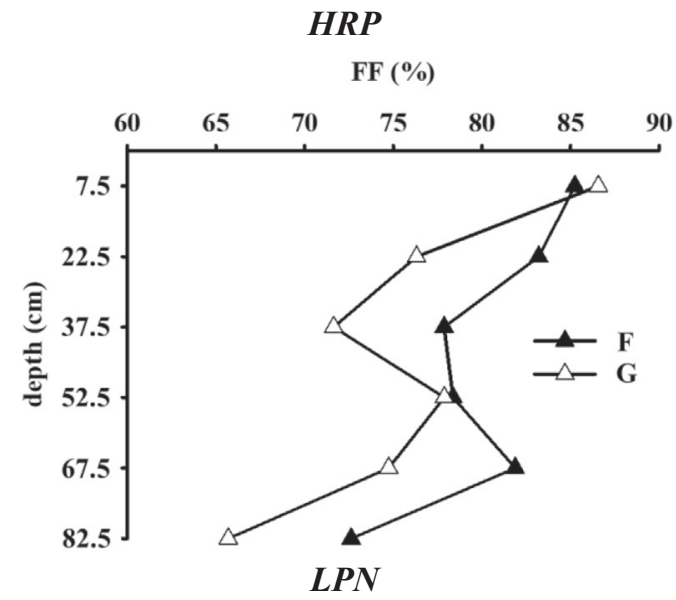

FF (\%)

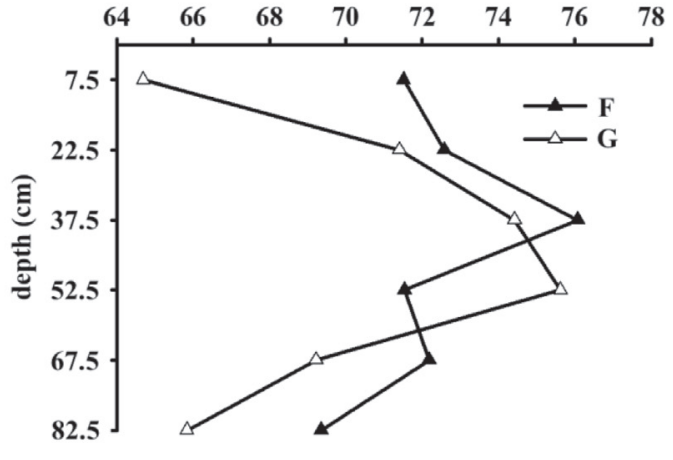

HRP

$\mathrm{C} / \mathrm{N}$

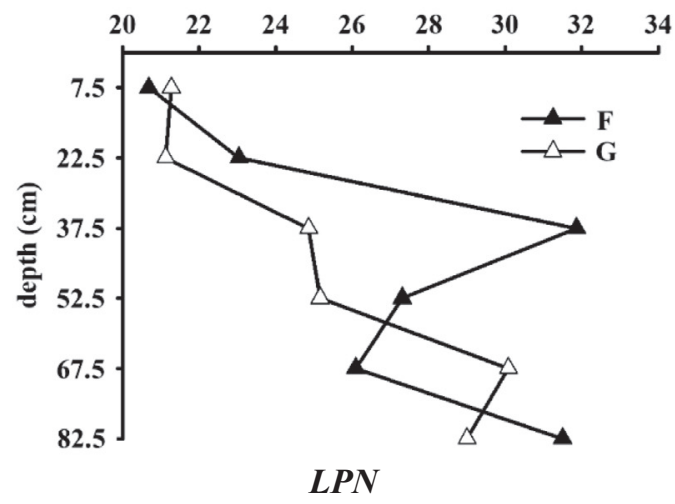

$\mathbf{C} / \mathbf{N}$

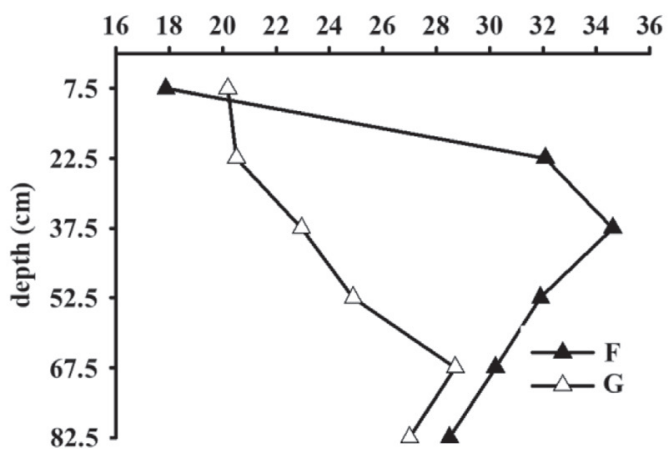

HAR

FF (\%)

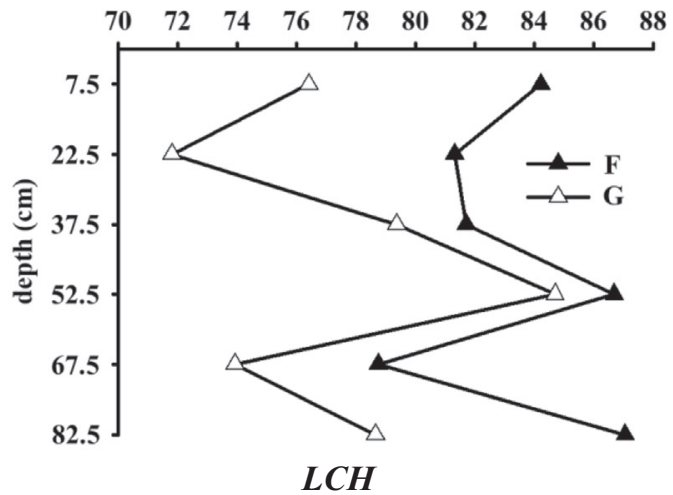

FF (\%)

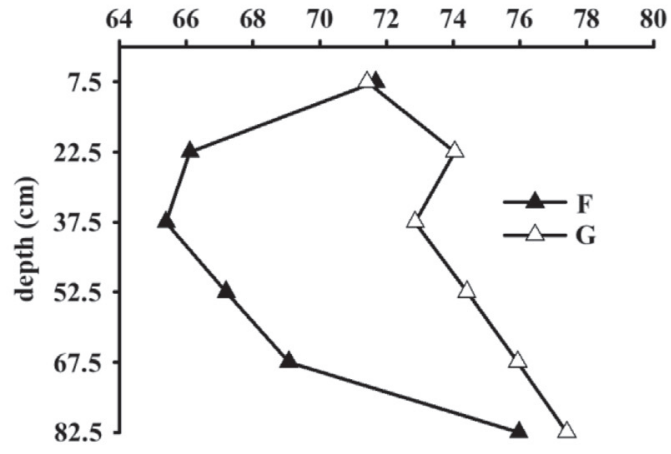

$\boldsymbol{H A R}$
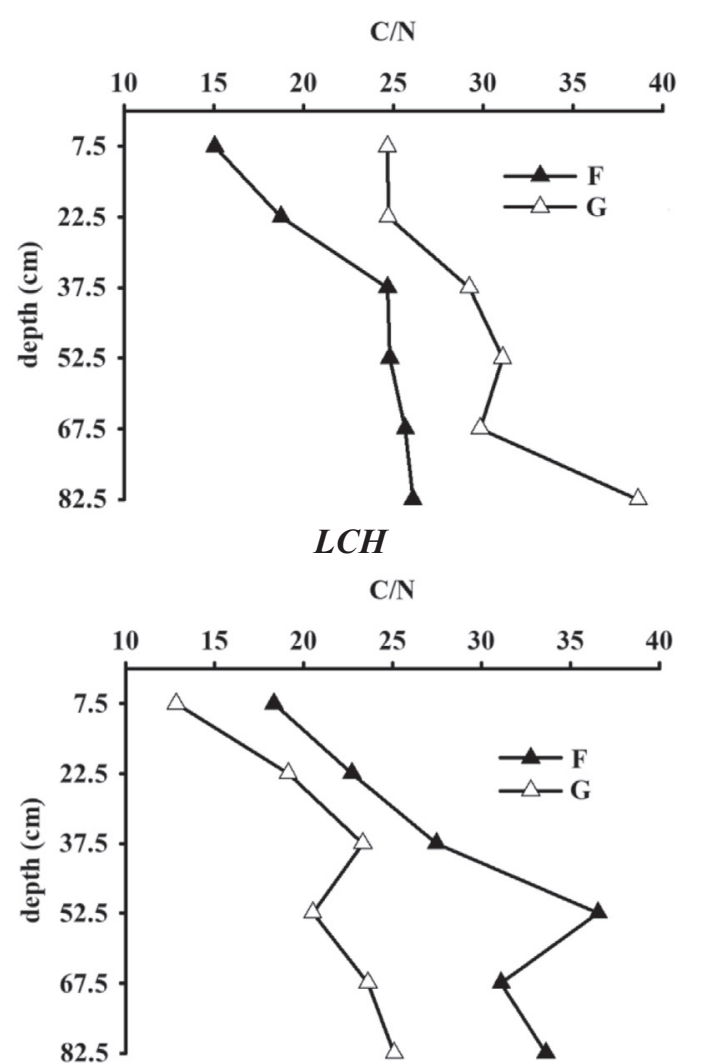

Fig. 3. Values of FF and $\mathrm{C} / \mathrm{N}$ ratio with respect to depth in $L P N, L C H, H R P$, and $H A R$ peatlands, under grassland $(G)$ and forest clusters $(F)$. 


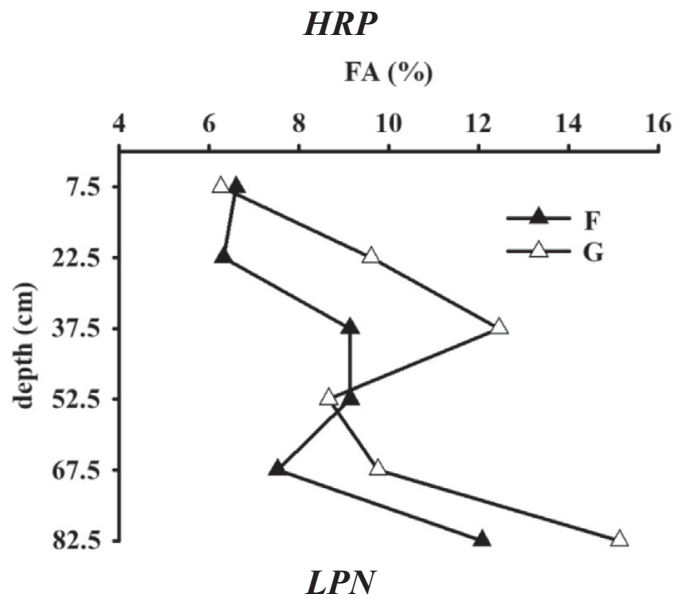

FA (\%)

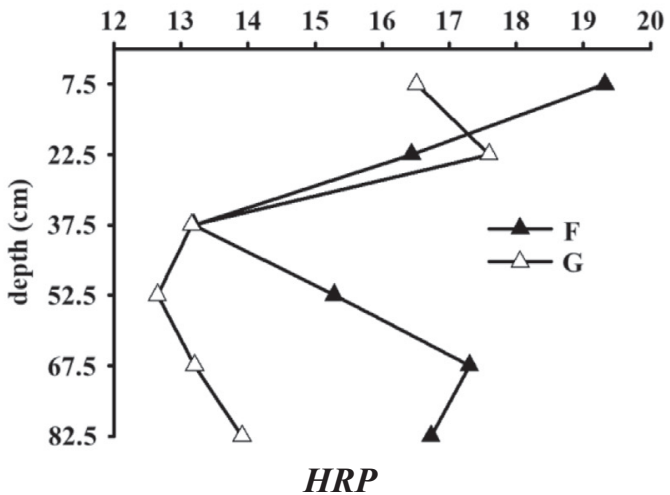

HA (\%)

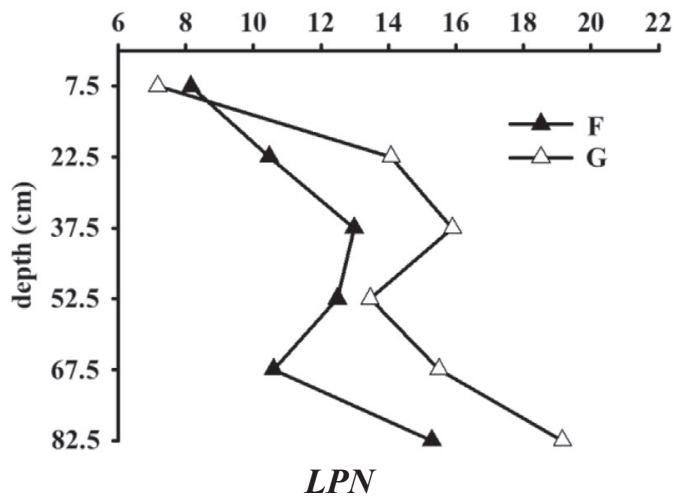

HA (\%)

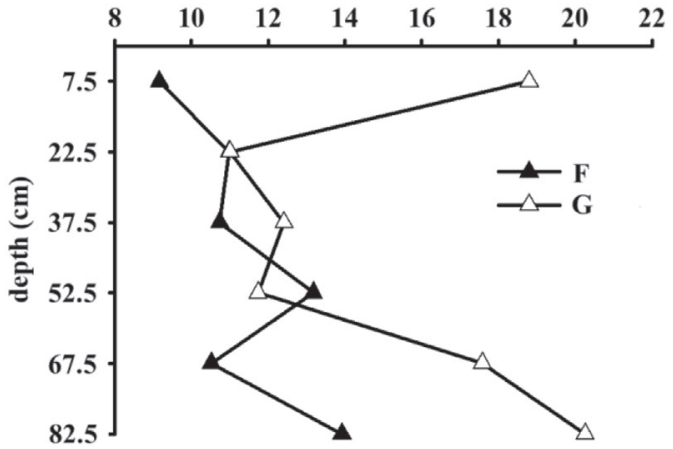

$\boldsymbol{H} \boldsymbol{A} \boldsymbol{R}$

FA (\%)

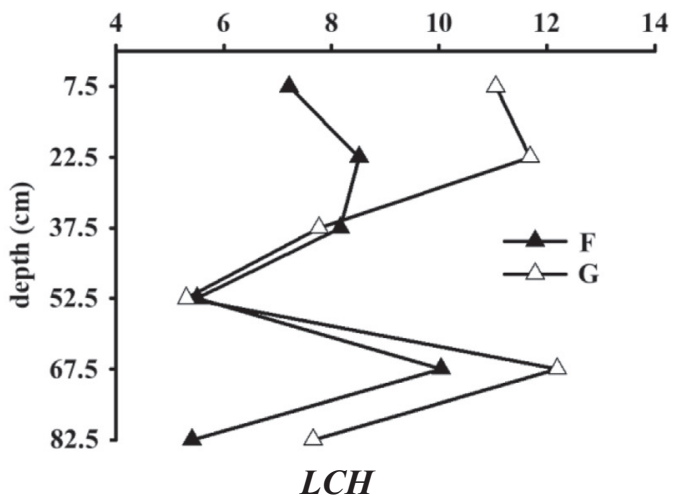

FA(\%)

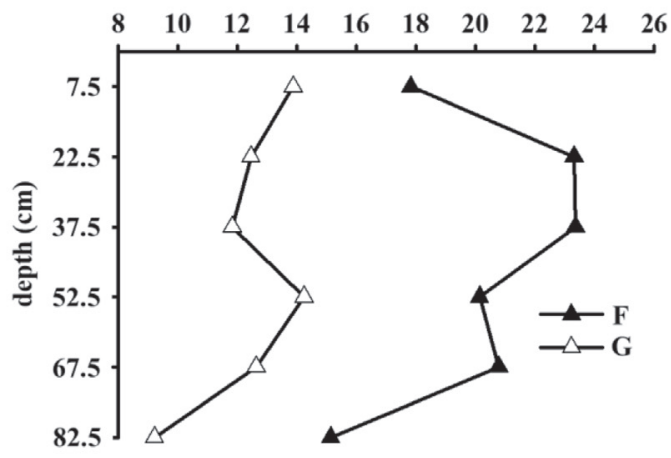

$H A R$

HA (\%)

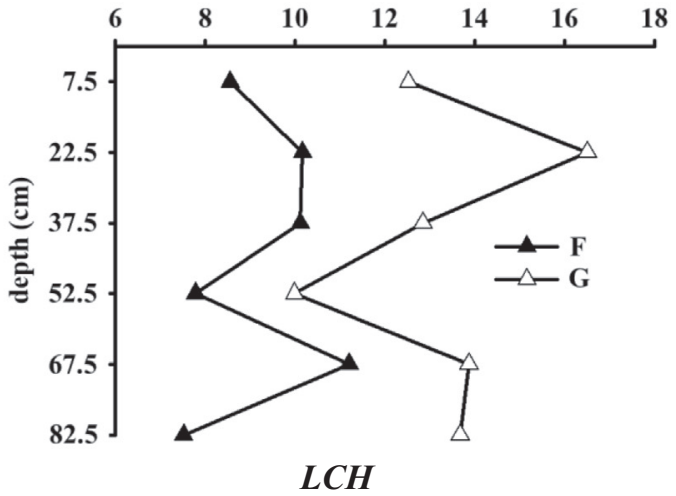

HA (\%)

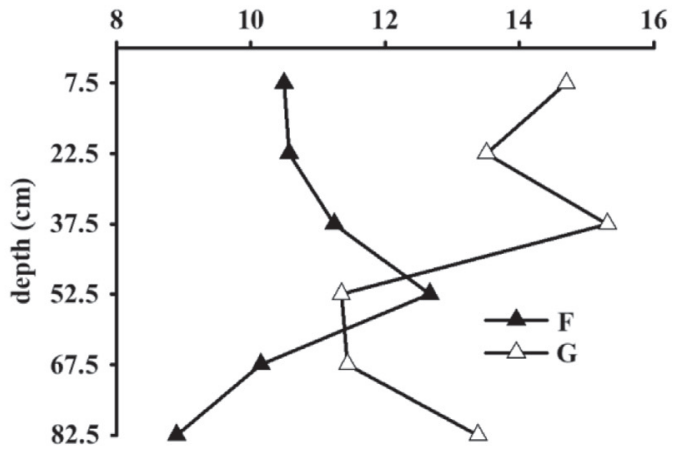

Fig. 4. Values of FA and HA with respect to depth in $L P N, L C H, H R P$, and $H A R$ peatlands, under grassland $(G)$ and forest clusters $(F)$. 

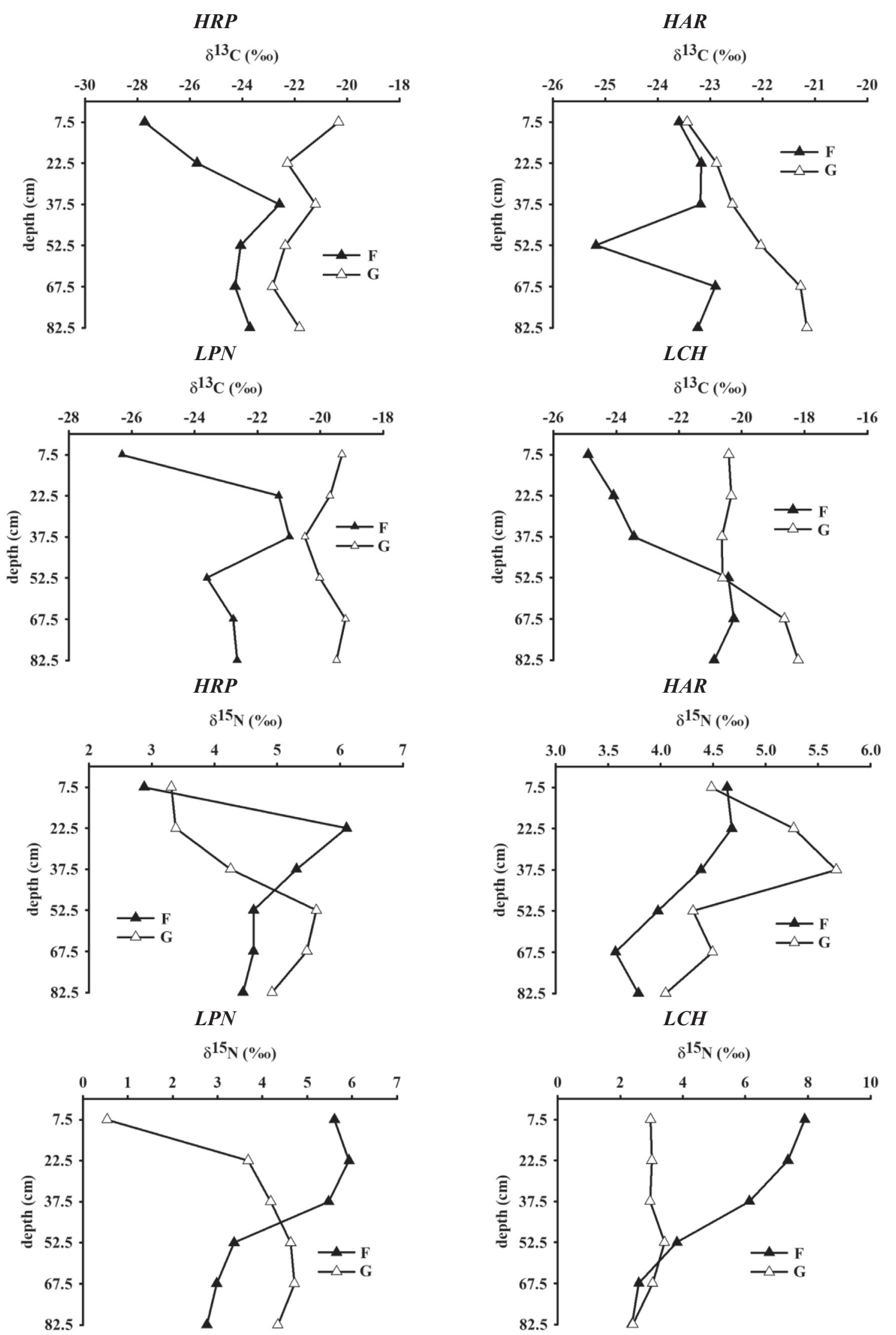

Fig. 5. Values of $\delta^{13} \mathrm{C}$ and $\delta^{15} \mathrm{~N}$ with respect to depth in $L P N, L C H, H R P$, and $H A R$ peatlands, under grassland (G) and forest clusters $(F)$. 
HRP

"van Soest lignin" (\%)

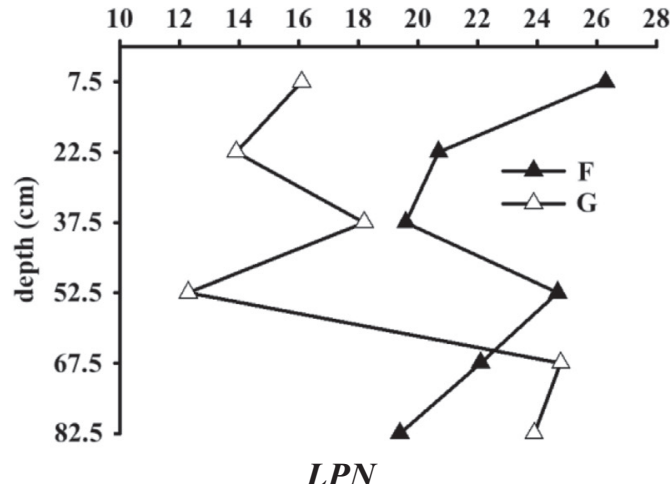

"van Soest lignin" (\%)

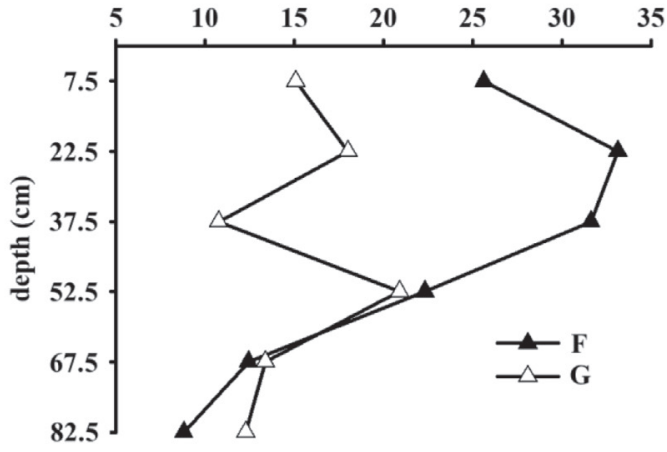

HRP

"van Soest cellulose" (\%)

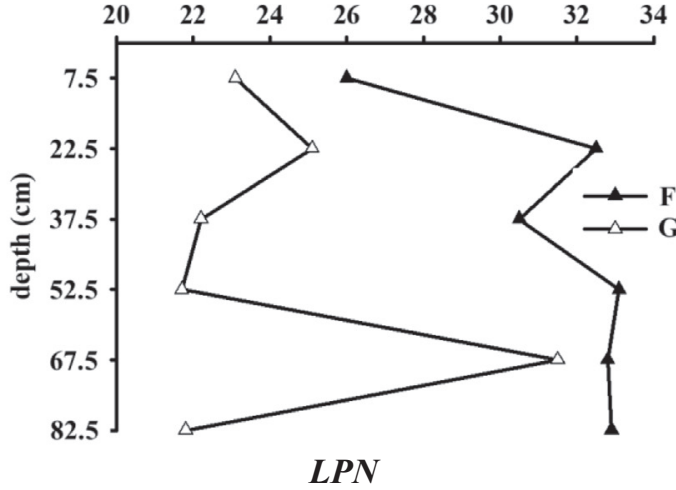

"van Soest cellulose" (\%)

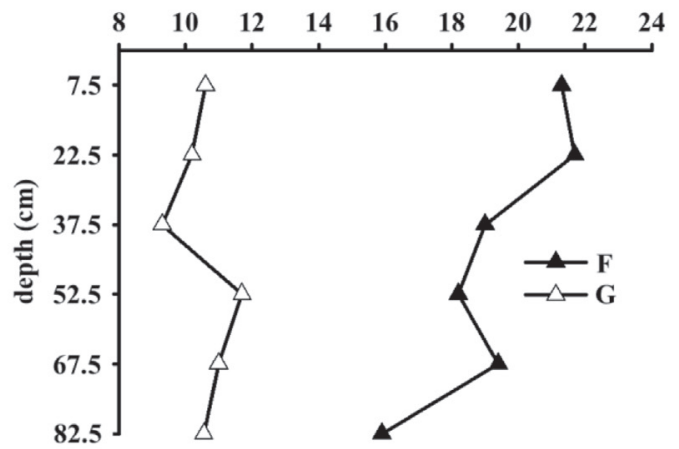

\section{HAR}

"van Soest lignin" (\%)

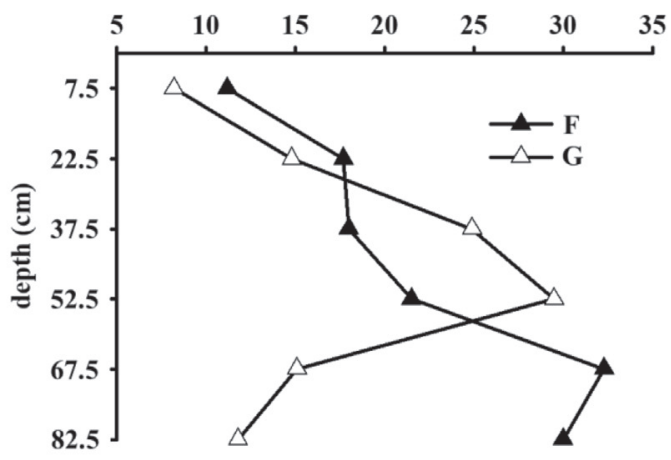

$\mathrm{LCH}$

"van Soest lignin" (\%)

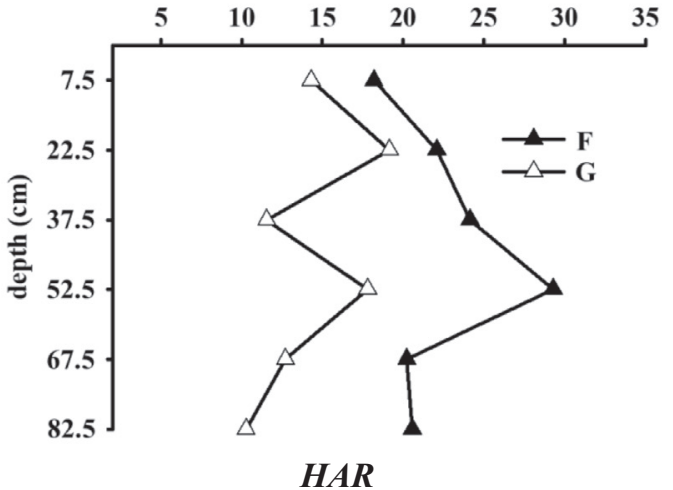

"van Soest cellulose" (\%)

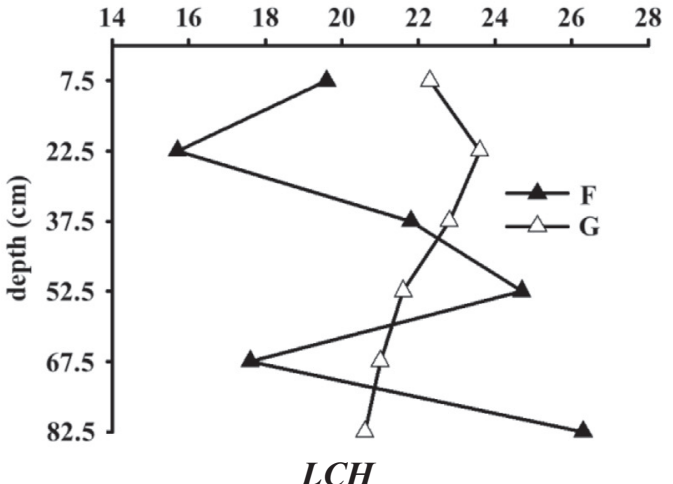

"van Soest cellulose" (\%)

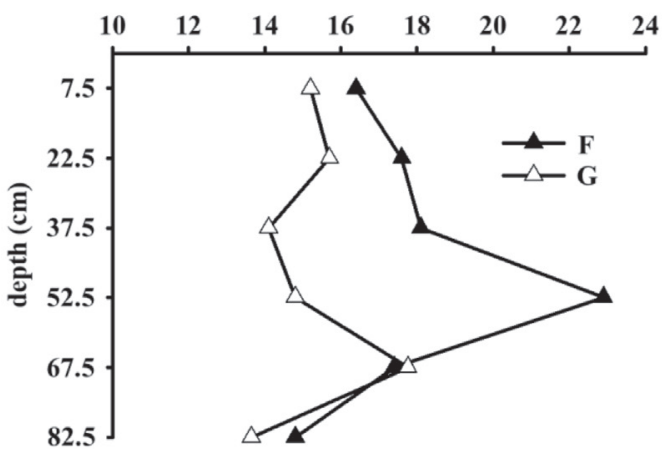

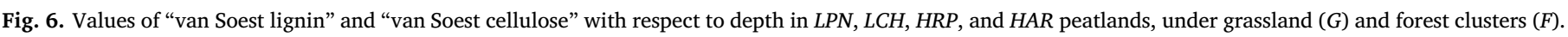




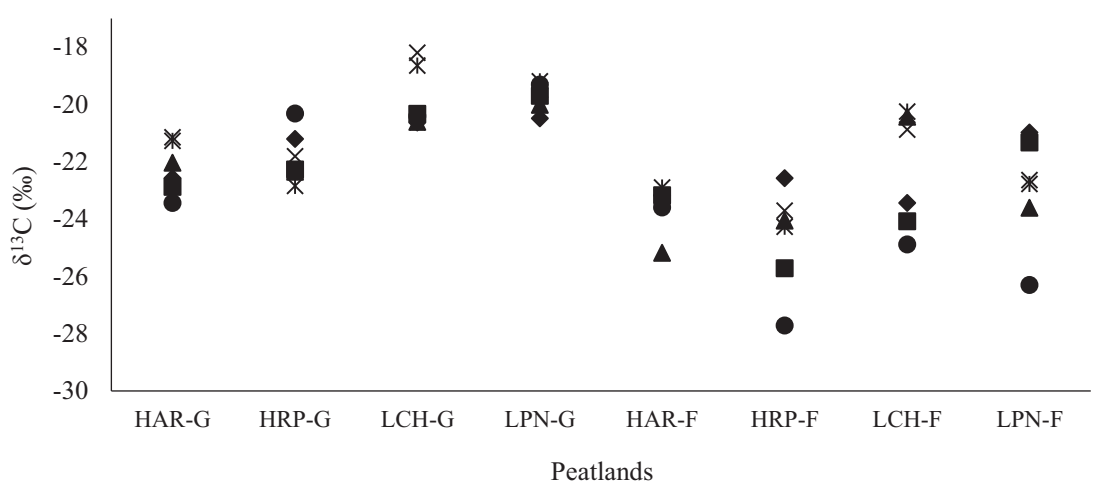

Fig. 7. Values of $\delta^{13} \mathrm{C}$ in peat organic matter in $L P N, L C H, H R P$, and $H A R$ peatlands, under grassland $(G)$ and forest clusters $(F)$.

Table 4

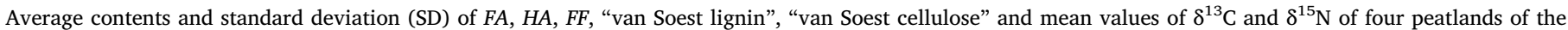
SdEM.

\begin{tabular}{|c|c|c|c|c|c|c|c|}
\hline \multirow[t]{2}{*}{ Peatland } & $F A$ & $H A$ & $F F$ & Lig & Cel & $\delta^{13} \mathrm{C}$ & $\delta^{15} \mathrm{~N}$ \\
\hline & \multicolumn{5}{|l|}{$\%$ of POM } & \multicolumn{2}{|l|}{$\%$} \\
\hline$H A R$ & $8.4 \mathrm{~b}(2.4)^{*}$ & $11.2 \mathrm{a}(2.7)$ & $80.4 a(4.8)$ & 19.6a (8.0) & $21.5 \mathrm{~b}(2.9)$ & $-22.9 \mathrm{a}(1.1)$ & $4.4 \mathrm{a}(0.6)$ \\
\hline HRP & $9.4 \mathrm{~b}(2.7)$ & $12.9 \mathrm{a}(3.4)$ & $77.7 \mathrm{a}(6.0)$ & $20.2 \mathrm{a}(4.4)$ & $27.7 \mathrm{a}(4.9)$ & $-23.2 \mathrm{a}(2.0)$ & $4.6 \mathrm{a}(1.0)$ \\
\hline$L P N$ & $15.4 \mathrm{a}(2.2)$ & $13.4 \mathrm{a}(3.7)$ & $71.2 b(3.6)$ & 18.7a (8.1) & $14.9 \mathrm{c}(4.8)$ & $-21.3 b(2.1)$ & $4.0 \mathrm{a}(1.5)$ \\
\hline $\mathrm{LCH}$ & $16.2 \mathrm{a}(4.7)$ & $12.0 \mathrm{a}(1.9)$ & $71.8 \mathrm{~b}(4.0)$ & $18.4 \mathrm{a}(5.6)$ & $16.6 c(2.6)$ & $-21.1 b(2.0)$ & $4.0 \mathrm{a}(2.0)$ \\
\hline
\end{tabular}

POM: peat organic matter; *: SD. Means followed by the same letter in the columns did not differ by Tukey's test (p $<0.05)$. $\mathrm{n}=12$.

and $L D 2$ ) shows a clear differentiation of peatlands by altitude. There is a greater proximity between samples of $R P$ and $A R$ peatlands, located at $1600 \mathrm{~m}$ in altitude, and between samples of $P N$ and $C H$, located at an altitude of $1300 \mathrm{~m}$ (Fig. 9).

The larger number of exclusive dominant species in the higher peatlands (LAR and LRP - Tables 1 and 2) in grasslands and forest clusters areas and the composition of organic matter (variables $A F, F F$, "van Soest cellulose" and $\delta^{13} \mathrm{C}-\mathrm{ANOVA}, \mathrm{p}=0,000$ ) show differences in the composition and stage of peat decomposition.

\section{Discussion}

\subsection{Influence of altitude in the floristic composition of the peatlands}

Almost all analyzed species present a $\mathrm{C}_{3}$ photosynthetic path, except for the two species of the Poaceae family, whose photosynthetic pathway is $\mathrm{C}_{4}$. Occurrence of $\mathrm{C}_{3}$ - and $\mathrm{C}_{4}$-cycle plants have been identified in tropical peatlands (Hillaire-Marcel et al., 1989; Aucour et al., 1994; Parolin et al., 2006) including those of SdEM (Campos et al., 2012; Horák et al., 2011; E.V. Silva et al., 2013; Horák-Terra et al., 2015). The $C_{4}$ species occur in the grasslands alone and are commonly found, especially in peatlands at higher altitudes. V.E. Silva et al. (2013) evaluated the values of $\delta^{13} \mathrm{C}$ in plant species that colonized a

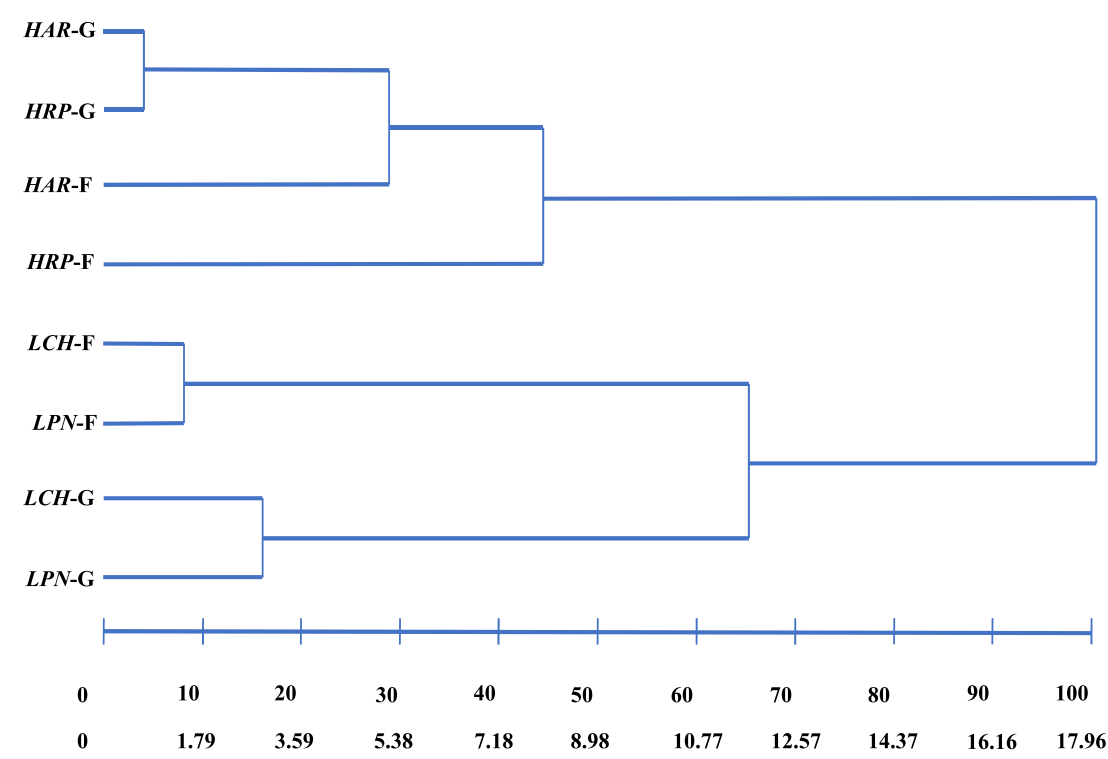

Fig. 8. Dendrogram of hierarchical cluster analysis concerning the locations and vegetation type of peatlands, in relation to FF, "van Soest lignin", "van Soest cellulose", $\delta^{13} \mathrm{C}$, and $\delta^{15} \mathrm{~N}$. 


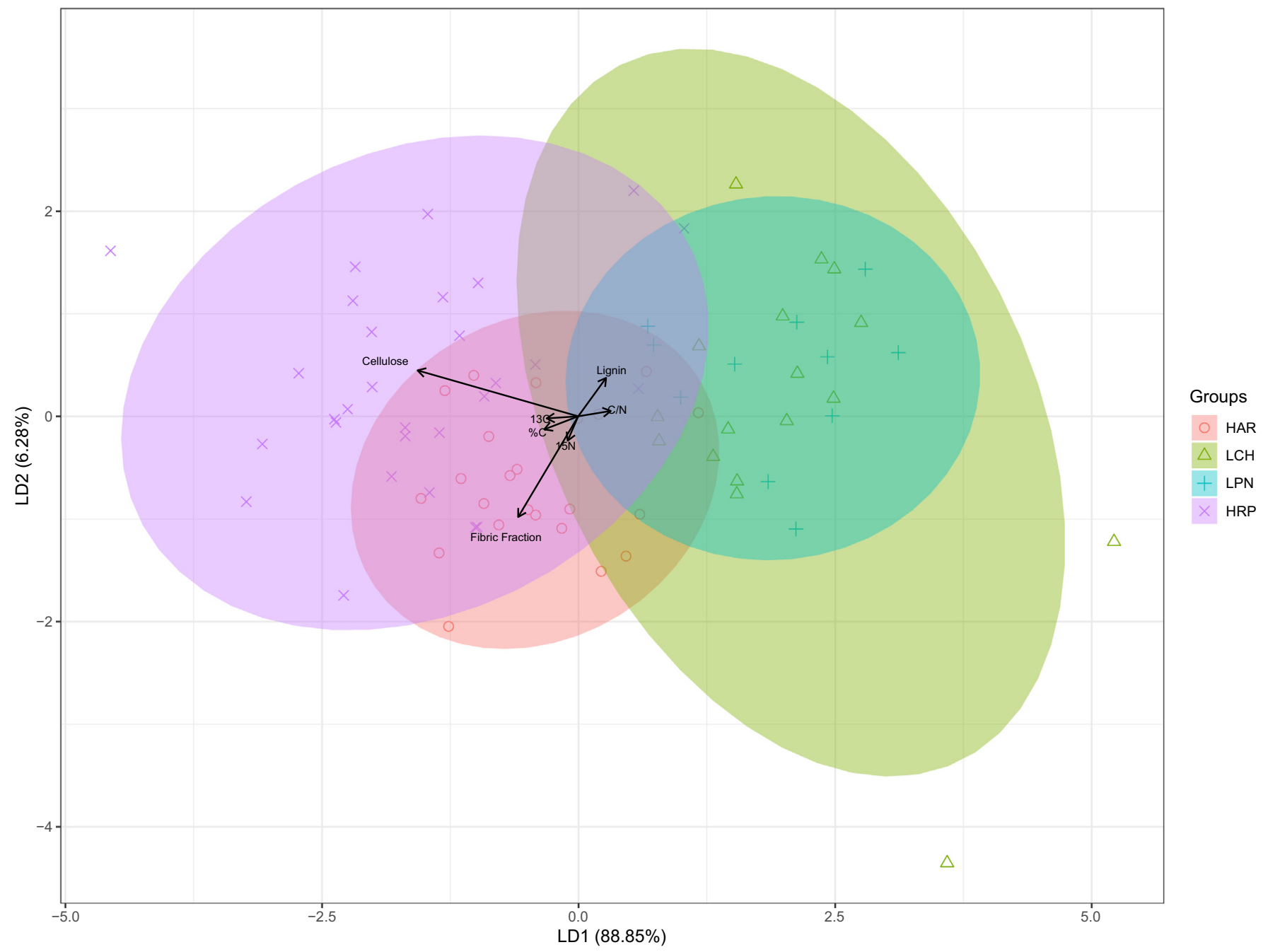

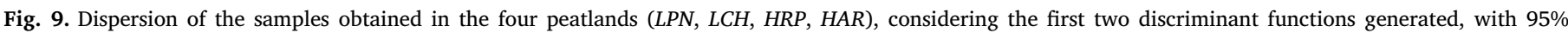
confidence ellipses.

peatland of SdEM situated at $1370 \mathrm{~m}$ altitude and obtained an average value of $-25.89 \%$ for grasslands species and $-29.91 \%$ for forest clusters species.

The families Cyperaceae, Eriocaulaceae, Iridaceae, Poaceae, and Xyridaceae, common to all the peatlands (Table 2) are among the most important in wetlands of SdEM and Central Brazil (Munhoz and Felfili, 2008). The Eriocaulaceae and Xyridaceae are small and thin herbs that, according to Munhoz and Felfili (2008), cover small areas in the grassland compared to species that form dense clumps, such as the Poaceae. Among the Cyperaceae, Lagenocarpus rigidus was one of the most frequently occurring species. According to Munhoz and Felfili (2008), this species is restricted to areas with a shallow water table. Meguro et al. (1996a) observed that Lagenocarpus species, together with other herbaceous species of different families are common in more humid grasslands.

The species Tapirira guianensis and Calophyllum brasiliense also occur in forest clusters situated in the Serra do Cipó, and in the Gallery Forest and Seasonal Semi-deciduous Forest (Meguro et al., 1996a,b; Santos et al., 2011). T. guianensis is very important in the initial colonization of grassland areas along watercourses, because it competes with herbaceous species, and it is also found in the dense forest clusters. The species Protium heptaphyllum and C. brasiliense were also found in the SdEM (Meguro et al., 1996a), including forest clusters of peatlands (E.V. Silva et al., 2013). All of these species are adapted to stress conditions resulting from area flooding (Meguro et al., 1996a), thus are of extreme importance for forest clusters formation in the peatlands.

Differences in floristic composition in the SdEM peatlands evaluated in this study were associated with altitude. $L C H$ and $L P N$ presented floristic composition different from $L R P$ and $L A R$ (Table 2).

\subsection{Influence of vegetation type and altitude on the content and} composition of soil organic matter

\subsubsection{Vegetation type}

The $F A$ mean contents were higher in peat under forest clusters, whereas the $H A$ mean contents were higher in peat under grasslands (Table 3). The FA contents of soils of Brazilian Forest Biomes (Amazonian Forest, Atlantic Forest, Caatinga and Cerrado) are higher than the $H A$ contents and the inverse is observed in the Brazilian Grassland Biome (Pampa) and in pastures (Santos et al., 2013).

The higher "van Soest lignin" content in forest clusters (Table 3) can be explained by the dominance of woody species. The organic matter produced by tree species is predominantly lignified (Christensen et al., 2000; Moreira et al., 2006).

The mean values of $\delta^{13} \mathrm{C}$ were lower under forest clusters than under grasslands (Table 3), and they were similar to those found by E.V. Silva et al. (2013) in the SdEM peatland under forest cluster and under grasslands. The grasslands currently present species of the $\mathrm{C}_{4}$ photosynthetic pathway (Poaceae - Table 2), which discriminate less against $\delta^{13} \mathrm{C}$ than the $\mathrm{C}_{3}$ photosynthetic pathway species that currently 


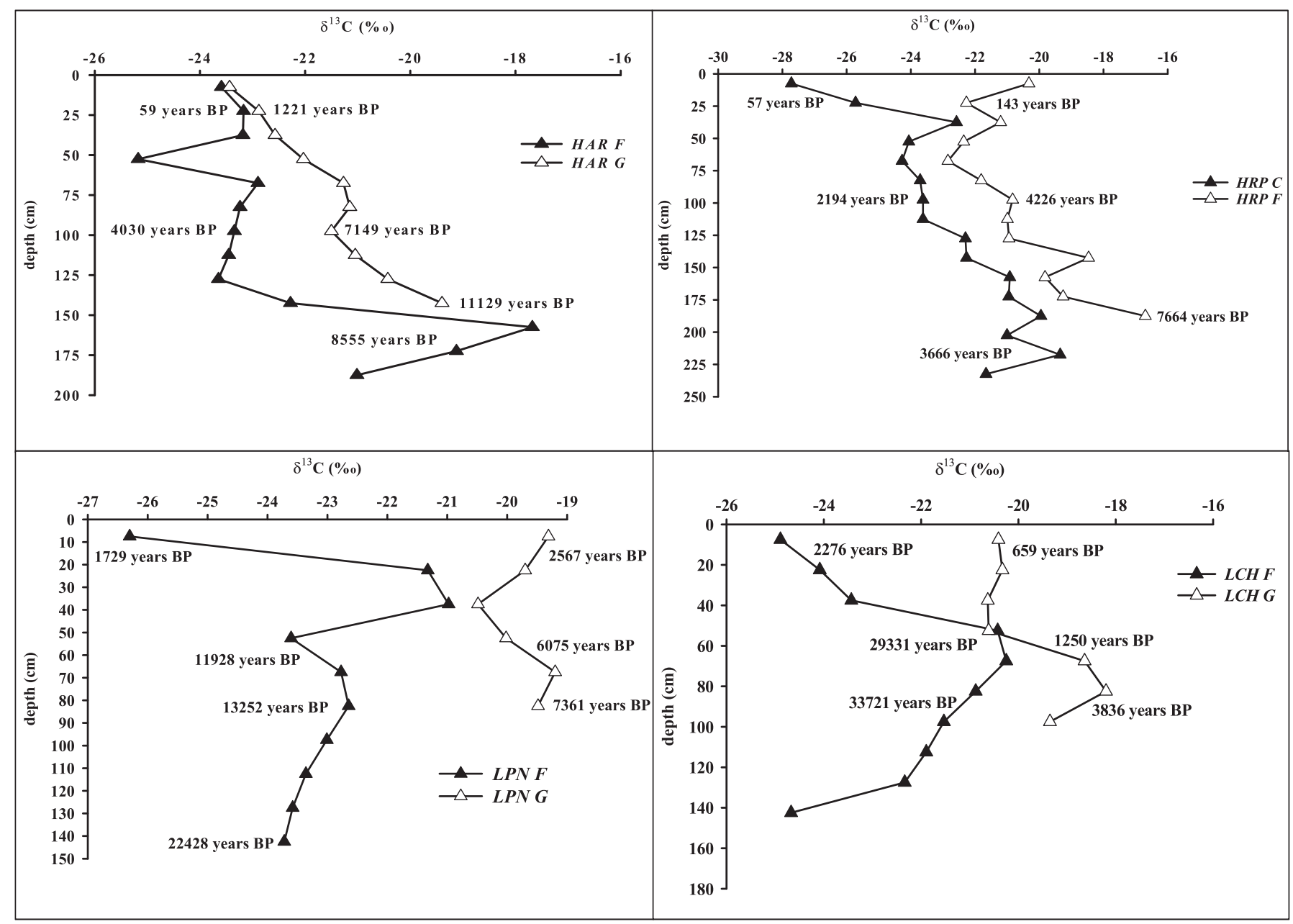

Fig. 10. $\delta^{13} \mathrm{C}$ values and radiocarbon dating with respect to depth in $L P N, L C H, H R P$, and HAR peatlands, under grassland $(G)$ and forest clusters $(F)$.

colonized by forest clusters. These $\mathrm{C} 4$ plant species are very abundant in the grassland. The lower mean values of $\delta^{13} \mathrm{C}$ in the superficial layer under forest clusters than under grasslands exhibit isotopic composition of peat organic matter similar to those of the vegetation type that currently colonizes it.

When the values of $\delta^{13} \mathrm{C}$ under the two vegetation types are considered, grasslands and forest clusters were clearly separated (Fig. 7), demonstrating the different isotopic composition of the peat organic matter between vegetation types that currently colonizes it. Similar results were found by E.V. Silva et al. (2013) in another peatland of SdEM.

4.2.1.1. Altitude. The $L C H$ and $L P N$ peatlands present differences in the levels of $F F, F A$, van Soest cellulose and $\delta^{13} \mathrm{C}$ compared to $H R P$ and $H A R$ peatlands (Table 4). The peatlands of higher altitudes, where annual average temperatures are 2 to $3^{\circ} \mathrm{C}$ lower, present a different species than peatlands of lower altitudes (Table 2). According to the Nernst equation the increase in temperature favors oxidation and, of course, the decay of the peat organic matter. Jassey et al. (2013) detected that the increase in temperature of the peats stimulated microbial activity, leading to slight increases in levels of nutrients and labile $C$ in peat water.

The mean levels of $F A$ (soluble) are higher and the mean levels of $F F$ are lower in peats of lower altitudes ( $L P N$ and $L C H$ - older) (Table 4), since decomposition is more pronounced at higher temperatures, and is accentuated over time. Schnitzer (1967) detected in peatlands of Canadá that the increased in humification of peat organic matter was associated with increases in $F A$ concentrations. The positive correlation between the peat ages and $F A(\mathrm{r}=0.37, \mathrm{n}=24$; $t$-test, $\mathrm{p}=0.038)$ also corroborates the continuous decomposition in the lower peatlands.

The higher mean value of $\delta^{13} \mathrm{C}$ found in the $L C H$ and $L P N$ peatlands (Table 4) may be related to a more advanced decomposition stage and indicates the admixture of microbial organic matter in peat organic matter, which generally has a higher content of the heavy isotopes (Buurman et al., 2004). The values of $\delta^{13} \mathrm{C}$ tend to increase in the deeper layers in all peatlands, under both vegetation types (Fig. 5), as observed by other authors (Horák-Terra et al., 2015; Bispo et al., 2016; Campos et al., 2016) in peatlands of the SdEM.

The $\mathrm{C} / \mathrm{N}$ ratio increases with depth (ANOVA, $\mathrm{p}=0.000$ ). In graminoid-dominated peat from northern Spain, the $\mathrm{C} / \mathrm{N}$ ration showed a gradual increase with depth (Martínez-Cortizas et al., 2007). In contrast to what was observed for peats with presence of sphagnum acid in temperate and boreal regions (Clymo, 1984; Kuhry and Vitt, 1996), the higher values of the $\mathrm{C} / \mathrm{N}$ ratio at depth can indicate greater decomposition of soil organic matter in these peatlands (Horák-Terra et al., 2014; Schellekens et al., 2015a). In several peatlands of SdEM, the superficial layers are fibric, the intermediates are hemic and the lower are sapric (van Post scale) indicating more advanced decomposition of the peat organic matter in depth (Bispo et al., 2015; Horák et al., 2011; Campos et al., 2011).

\subsection{Chronological succession of grassland and forest clusters in peatlands}

Forests clusters of lower altitudes peatlands began to settle in the Late Pleistocene and forests clusters of higher altitudes peatlands settled in the Holocene (Fig. 10). According to Parrenin et al. (2013), ice cores 
showed average temperatures in the Antarctic from -9 to $-5{ }^{\circ} \mathrm{C}$ and -5 to $-2{ }^{\circ} \mathrm{C}$ below the current mean, respectively between 55,000 and 16,400 years BP and between 16,400 and 12,800 years BP. Between 12,800 - and 8800 -years $\mathrm{BP}$, the average temperatures varied from +2 to $-1{ }^{\circ} \mathrm{C}$ in relation to the current average temperatures. These data are in line with most of the paleoclimatic changes identified in the SdEM peatlands by multi-proxy studies (Horák-Terra, 2014; Horák-Terra et al., 2015; Costa, 2018) and are related with the colonization of peatlands of higher altitudes by forest clusters only in the Holocene.

\section{Conclusions}

1. The organic matter of peatlands currently under grasslands and forest clusters presented differences in the soluble fractions, the lignocellulosic composition, and $\delta^{13} \mathrm{C}$ values.

2. Multivariate analysis (FF, "van Soest lignin", "van Soest cellulose", $\mathrm{C} / \mathrm{N}, \delta^{13} \mathrm{C}$, and $\delta^{15} \mathrm{~N}$ ) allowed the peatlands to be grouped by altitude and vegetation type.

3. The chronological succession of grassland and forest clusters in tropical mountain peatlands was influenced by altitude and was related to paleoclimatic changes.

\section{Acknowledgments}

We thank the Universidade Federal dos Vales do Jequitinhonha e Mucuri for institutional support, the Parque Estadual do Rio Preto for technical support, the CNPq, FAPEMIG (grant CAG - APQ-01614-14 and PPM 00568-16) for financial support and scholarships. "This study was financed in part by the Coordenação de Aperfeiçoamento de Pessoal de Nível Superior - Brasil (CAPES) - Finance Code 001" and CAPES (PNPD $2606 / 2011$, grant No. 2338007759/2011-52). The authors are in debt to professor David Lee Nelson (UFVJM) for kindly reading the manuscript and for all suggestions presented, particularly those concerning the English language. The authors also thank the anonymous reviewers and the editors for their careful reading and their insightful remarks, which helped us to improve the quality of our manuscript.

\section{Appendix A. Supplementary data}

Supplementary data to this article can be found online at https:// doi.org/10.1016/j.catena.2019.04.017.

\section{References}

Aucour, A.M., Hillaire-Marcel, C., Bonnefille, R., 1994. Late Quaternary biomass changes from ${ }^{13} \mathrm{C}$ measurements in a highland peatbog from Equatorial Africa (Burundi). Quat. Res. 41, 225-233. https://doi.org/10.1006/qres.1994.1024.

Bispo, D.A., Silva, A.C., Christofaro, C., Silva, M.L.N., Barbosa, M.S., Silva, B.P.C., Barral, U.M., 2015. Characterization of headwaters peats of the Rio Araçuaí, Minas Gerais state, Brazil. Rev. Bras. Ci. Solo 39, 475-489. https://doi.org/10.1590/ 01000683 rbcs20140337.

Bispo, D.F.A., Silva, A.C., Christófaro, C., Silva, M.L.N., Barbosa, M.S., Silva, B.P.C., Barral, U.M., Fabris, J.D., 2016. Hydrology and carbon dynamics of tropical peatlands from Southeast Brazil. Catena 143, 18-25. https://doi.org/10.1016/j.catena. 2016.03.040.

Buurman, P., Roscoe, R., Alcantara, F., 2004. Carbon sequestration research in Brazilian savannah systems: problems and results. Edafologia 11, 157-170.

Campos, J.R.R., Silva, A.C., Fernandes, J.S.C., Ferreira, M.M., Silva, D.V., 2011. Water retention in a peatland with organic matter in different decomposition stages. Rev. Bras. Ci. Solo. 35, 1217-1227. https://doi.org/10.1590/S0100-6832011000400015.

Campos, J.R.R., Silva, A.C., Vidal-Torrado, P., 2012. Mapping, organic matter mass and water volume of a peatland in Serra do Espinhaço Meridional. R. Bras. Ci. Solo. 36, 723-732. https://doi.org/10.1590/S0100-06832012000300004.

Campos, R. J. R., Silva, A. C., Slater, L., Nanni, M. R., Vidal-Torrado, P., 2016. Stratigraphic control and chronology of peat bog deposition in the Serra do Espinhaço Meridional, Brazil. Catena. 143, 167-173.ttp://dx.doi.org/10.1016/j.catena.2016. 04.009.

Canellas, L.P., Santos, G.A., 2005. Humosfera: tratado preliminar sobre a química das substâncias húmicas, ed. UENF, Campos dos Goytacazes.

Christensen, J.H., Baucher, M., O'Connell, A., Van Montagu, M., Boerjan, W., 2000. Control of lignin biosynthesis. In: Jain, S.M., Minocha, S.C. (Eds.), Molecular Biology of Woody Plants. Kluwer Academic Publishers Norwell, pp. 227-267.
Clymo, R.S., 1984. The limits to peat bog growth. Phil. Trans. R. Soc. Lond. B. 303, 605-654.

Costa, C. R. 2018. Estudo de reconstituição paleoambiental utilizando uma abordagem multi-proxy em um registro da turfeira do Rio Preto, Minas Gerais, Brasil. (MSc Thesis). Universidade Federal dos Vales do Jequitinhonha e Mucuri. Brazil.

Cruz, C.D., 2006. Programa Genes: estatística experimental e matrizes, UFV. In: Viçosa.

Dury, G.H., 1972. High temperature extremes in Australia. Ann. Assoc. Am. Geogr. 62, $388-400$.

Evans, R.D., 2007. Soil nitrogen isotope composition. In: Michener, R., Lajtha, K. (Eds.), Stable Isotopes in Ecology and Environmental Science, second ed. Blackwell Publishing, pp. 83-98.

Groning, M., Groot, P.A., 2004. Handbook of Stable Isotope Analytical Techniques. Elsevier, Amsterdam.

Hair, J.F., Anderson, R., Barry, B., 2009. Multivariate Data Analysis: A Global Perspective, 7th ed. Prentice Hall. Print, Upper Saddle River.

Hillaire-Marcel, C., Aucour, A.M., Bonnefille, R., Riollet, G.,Vincens, A., Williamson, D., 1989. 13C/palynological evidence of differential residence times of organic carbon prior to its sedimentation in East African rift lakes and peat bogs. Quat. Sci. Rev. 8, 207-212. https://doi.org/10.1016/0277-3791(89)90037-1.

Horák, I., Vidal-Torrado, P., Silva, A.C., Pessenda, L.C.R., 2011. Pedological and isotopic relations of a highland tropical peatland, Mountain Range of the Espinhaço Meridional (Brazil). R. Bras. Ci. Solo. 35, 41-52. https://doi.org/10.1590/S010006832011000100004.

Horák-Terra, I. Late Pleistocene-Holocene environmental change in Serra do Espinhaço Meridional (Minas Gerais state, Brazil) reconstructed using a multi-proxy characterization of peat cores from mountain tropical mires. 2014. (Doutoral Thesis) Universidade de São Paulo, Brazil.

Horák-Terra, I., Martínez-Cortizas, A., Camargo, P.B., Silva, A.C., Vidal-Torrado, P., 2014. Characterization of properties and main processes related to the genesis and evolution of tropical mountain mires from Serra do Espinhaço Meridional, Minas Gerais, Brazil. Geoderma. 232-234, 183-197. https://doi.org/10.1016/j.geoderma.2014.05. 008 .

Horák-Terra, I., Martínez-Cortizas, A., Luz, C.F.P., Rivas-López, P., Silva, A.C., VidalTorrado, P., 2015. Holocene climate change in central-eastern Brazil reconstructed using pollen and geochemical records of Pau de Fruta mire (Serra do Espinhaço Meridional, Minas Gerais). Palaeogeogr. Palaeoclimatol. Palaeoecol. 437, 117-131. https://doi.org/10.1016/j.palaeo.2015.07.027.

Jassey, V.E., Chiapusio, G., Binet, P., Buttler, A., Laggoun-Défarge, F., Delarue, F., Bernard, N., Mitchell, E.A., Toussaint, M.L., Francez, A.J., Gilbert, D., 2013. Aboveand below ground linkages in Sphagnum peatland: climate warming affects plantmicrobial interactions. Glob. Chang. Biol. 19, 811-823. https://doi.org/10.1111/gcb. 12075.

Johnson, R., Wichern, D., 1992. Applied Multivariate Statistical Methods, third ed. Prentice Hall, New Jersey.1038/ncomms13630.

Klock, U., Muñiz, G.I.B.D., Hernandez, J.A., Andrade, A.D., 2005. Química da madeira, UFPR. In: Curitiba.

Kuhry, P., Vitt, D.H., 1996. Fossil carbon/nitrogen ratios as a measure of peat decomposition. Ecology 77, 271-275.

Lehmann, M. F., Bernasconi, S. M., Barbieri, A., Mckenzie, J. A., 2002. Preservation of organic matter and alteration of its carbon and nitrogen isotope composition during simulated and in situ early sedimentary diagenesis. Geochimica et Cosmochimica Acta, v.66, p.3573-3584, 2002.https://doi.org/10.1016/S0016-7037(02)00968-7.

Martínez-Cortizas, A., Biester, H., Mighall, T., Bindler, R., 2007. Climate-driven enrichments of pollutants in peatlands. Biogeosciences 4, 905-911.

Meguro, M., Pirani, J.R., Mello-Silva, R., Giulietti, A.M., 1996a. Estabelecimento de matas ripárias e capões nos ecossistemas campestres da Cadeia do Espinhaço. Minas Gerais. Boletim de Botânica da Universidade de São Paulo 1-11.

Meguro, M., Pirani, J.R., Mello-Silva, R., Giulietti, A.M., 1996b. Caracterização florística e estrutural de matas ripárias e capões de altitude da Serra do Cipó. Minas Gerais. Boletim de Botânica da Universidade de São Paulo 13-29.

Mendonça Filho, C. V., 2005. Vegetação, in: Silva, A. C.; Pedreira, L. C. V. S. F., Abreu, P. A. A. (Eds.). Serra do Espinhaço Meridional: Paisagens e Ambientes, O lutador, Belo Horizonte, pp.118-126.

Moreira, J.N., Lira, M.D.A., Santos, M.D., Ferreira, M.D.A., Araújo, G.D., Ferreira, R.L.C., Silva, G.D., 2006. Caracterização da vegetação de Caatinga e da dieta de novilhos no Sertão de Pernambuco. Pesq. Agropec. Bras. 41, 1643-1651. https://doi.org/10. 1590/S0100-204X2006001100011.

Munhoz, C.B.R., Felfili, J.M., 2008. Fitossociologia do estrato herbáceo-subarbustivo em Campo Limpo Úmido no Brasil Central. Acta bot. bras. 22, 905-913. https://doi.org/ 10.1590/S0102-33062008000400002.

Ometto, J.C., 1981. Bioclimatologia vegetal. In: Ed. Agronômica Ceres, São Paulo.

Parolin, M., Medeanic, S., Stevaux, J.C., 2006. Registros palinológicos e mudanças ambientais durante o Holoceno de Taquarussu (MS). R. Bras. Paleo. 9, 137-148.

Parrenin, F., Masson-Delmotte, V., Köhler, P., Raynaud, D., Paillard, D., Schwander, J., Barbante, C., Landais, A., Wegner, A., Jouzel, J., 2013. Synchronous change of atmospheric $\mathrm{CO}_{2}$ and Antarctic temperature during the last deglacial warming. Science. 339, 1060-1063. https://doi.org/10.1126/science.1226368 https://doi.org/10. 1016/j.palaeo.2010.09.008.

Pessenda, L. C. R., Camargo, P. B. de, Cruz, M. V. L., Lisi, C. S., Valencia, E. P. E., 1983. O Laboratório de Radiocarbono do CENA/USP no Programa Internacional de Intercooperação Laboratorial de Resultados. Quím. Nova. 16, 221-223.

Peterson, B.J., Howard, R.W., 1987. Sulfur, carbon, and nitrogen isotopes used to trace organic matter flow in the salt-marsh estuaries of Sapelo Island, Georgia. Limnology and Oceanography, Grafton 32 (6), 1195-1213.

Rezanezhad, F., Price, J.S., Quinton, W.L., Lennartz, B., Milojevic, T., Van Cappellen, P., 2016. Structure of peat soils and implications for water storage, flow and solute 
transport: a review update for geochemists. Chemical Geology 429, 75-84. https:// doi.org/10.1016/j.chemgeo.2016.03.010.

Ribeiro, K.T., Nascimento, J.S., Madeira, J.A., Ribeiro, L.C., 2009. Aferição dos limites da Mata Atlântica na Serra do Cipó, MG, Brasil, visando maior compreensão e proteção de um mosaico vegetacional fortemente ameaçado. Nat. \& Conserv. 7, 30-48.

Rudiyanto, G., Setiawan, B.I., Arief, C., Saptomo, S.K., Gunawan, A., Kuswarman, Sungkono, Indriyanto, H., 2015. Estimating distribution of carbon stock in tropical peatland using a combination of an empirical peat depth model and GIS. Procedia Environ. Sci. 24, 152-157. https://doi.org/10.1016/j.proenv.2015.03.020.

Santos, M.F., Serafim, H., Sano, P.T., 2011. Fisionomia e composição da vegetação florestal na Serra do Cipó, MG, Brasil. Acta bot. bras. 25, 793-814. https://doi.org/10 1590/S0102-33062011000400007.

Santos, L.L., Lacerda, J.J.J., Zinn, Y.L., 2013. Partição de substâncias húmicas em solos brasileiros. R. Bras. Ci. Solo. 37, 955-968. http://dx.doi.org/ https://doi.org/10. 1590/S0100-06832013000400013.

Schellekens, J., Buurman, P., Kuyper, T.W., 2012. Source and transformations of lignin in Carex-dominated peat. Soil Biol. Biochem. 53, 32-42.

Schellekens, J., Bradley, J.A., Kuyper, T.W., Fraga, I., Pontevedra-Pombal, X., VidalTorrado, P., Abbott, G.D., Buurman, P., 2015a. The use of plant-specific pyrolysis products as biomarkers in peat deposits. Quat. Sci. Rev. 123, 254-264. https://doi. org/10.1016/j.quascirev.2015.06.028.

Schellekens, J., Blinder, R., A, J., Martinez-Cortizas, A., McClymont, E.L., Abbott, G.D., Biester, H., Pontevedra-Pombal, X., Buurman, P., 2015b. Preferential degradation of polyphenols from Sphagnum - 4-isopropenylphenol as a proxy for past hydrological conditions in Sphagnum-dominated peat. Geochimica et Cosmochimica Acta 150, 74-89. https://doi.org/10.1016/j.gca.2014.12.003.

Schnitzer, M., 1967. Humic-fulvic acid relationships in organic soils and humification of the organic matter in these soils. Can. J. Soil Sci. 47, 245-250. https://doi.org/10. 4141/cjss67-038.
Silva, M.L., Silva, A.C., Silva, B.P.C., Barral, U.M., Soares, P.G.S., Vidal-Torrado, P., 2013a. Surface Mapping, organic matter and water stocks in peatlands of the Serra do Espinhaço Meridional - Brazil. R. Bras. Ci. Solo. 37, 1149-1157. https://doi.org/10. 1590/S0100-06832013000500004.

Silva, V.E., Silva, A.C., Pereira, R.C., Camargo, P.B., Silva, B.P.C., Barral, U.M., Mendonça Filho, C.V., 2013b. Composição lignocelulósica e isótopica da vegetação e da matéria orgânica do solo de uma turfeira tropical: II-Substâncias húmicas e processo de humificação. R. Bras. Ci. Solo. 37, 121-133. https://doi.org/10.1590/S010006832013000100014.

Silva, E.V., Silva, A.C., Pereira, R.C., Camargo, P.B., Silva, B.P.C., Barral, U.M., Mendonca Filho, C.V., 2013c. Composição lignocelulósica e isótopica da vegetação e da matéria orgânica do solo de uma turfeira tropical: I - composição florística, fitomassa e acúmulo de carbono. R. Bras. Ci. Solo. 37, 121-133. https://doi.org/10.1590/S0100 06832013000100013.

Stuiver, M., Reimer, P.J., Reimer, R.W., 2017. CALIB 7.1. [WWW program] at. http:// calib.org, Accessed date: 29 March 2017.

Tipple, B.J., Pagani, M., 2007. The Early Origins of Terrestrial $\mathrm{C}_{4}$ Photosynthesis. Annu. Rev. Earth Planet. Sci. 35, 435-461. https://doi.org/10.1146/annurev.earth.35. 031306.140150.

Valladares, G.S., Gomes, E.G., Mello, J.C.C.B.S., Pereira, M.G., Anjos, L.H.C., Ebeling, A.G., Benites, V.M., 2008. Análise dos componentes principais e métodos multicritério ordinais no estudo de Organossolos e solos afins. R. Bras. Ci. Solo. 32, 285-296. https://doi.org/10.1590/S0100-06832008000100027.

van Soest, P.J., 1994. Nutritional Ecology of the Ruminant. Cornell University Press, New York.

Veloso, H.P., Rangel Filho, A.L.R., Lima, J.C.A., 1991. Classificação da vegetação brasileira adaptada a um sistema universal. FIBGE, Rio de Janeiro.

Williams, C.J., Yavitt, J.B., 2003. Botanical composition of peat and degree of peat decomposition in three temperate peatlands. Ecoscience 10, 85-95. 